\title{
Inhibitory Immune Checkpoint Molecules and Exhaustion of $T$ cells in COVID-19
}

\author{
Martina BARNOVA ${ }^{1}$, Anna BOBCAKOVA ${ }^{2}$, Veronika URDOVA ${ }^{2,3}$, Radovan \\ KOSTURIAK $^{4}$, Lenka KAPUSTOVA ${ }^{5}$, Dusan DOBROTA ${ }^{6,7}$, Milos JESENAK ${ }^{1,2,5}$
}

${ }^{1}$ Department of Clinical Immunology and Allergology, University Hospital in Martin, Martin, Slovak Republic, ${ }^{2}$ Centre for Primary Immunodeficiencies, Clinic of Pneumology and Phthisiology, Jessenius Faculty of Medicine in Martin, Comenius University in Bratislava, University Hospital in Martin, Martin, Slovak Republic, ${ }^{3}$ Second Clinic of Internal Medicine, Slovak Medical University, Faculty Teaching Hospital of F.D. Roosevelt, Banska Bystrica, Slovak Republic, ${ }^{4}$ Out-patient Department of Clinical Immunology and Allergology LEKARTIN, Nitra, Slovak Republic, ${ }^{5}$ Centre for Primary Immunodeficiencies, Clinic of Pediatrics, Jessenius Faculty of Medicine in Martin, Comenius University in Bratislava, University Hospital in Martin, Martin, Slovak Republic, ${ }^{6}$ Department of Clinical Biochemistry, Jessenius Faculty of Medicine in Martin, Comenius University in Bratislava, University Hospital in Martin, Martin, Slovak Republic, ${ }^{7}$ Institute of Medical Biochemistry, Jessenius Faculty of Medicine in Martin, Comenius University in Bratislava, Martin, Slovak Republic

Received July 7, 2021

Accepted August 26, 2021

\section{Summary}

COVID-19 (Coronavirus Disease) is an infectious disease caused by the coronavirus SARS-CoV-2 (Severe acute respiratory syndrome Coronavirus 2), which belongs to the genus Betacoronavirus. It was first identified in patients with severe respiratory disease in December 2019 in Wuhan, China. It mainly affects the respiratory system, and in severe cases causes serious lung infection or pneumonia, which can lead to the death of the patient. Clinical studies show that SARS-CoV-2 infection in critical cases causes acute tissue damage due to a pathological immune response. The immune response to a new coronavirus is complex and involves many processes of specific and non-specific immunity. Analysis of available studies has shown various changes, especially in the area of specific cellular immunity, including lymphopenia, decreased $\mathrm{T}$ cells $\left(\mathrm{CD}^{+}, \mathrm{CD}^{+}\right.$and $\mathrm{CD}^{+}$), changes in the $\mathrm{T}$ cell compartment associated with symptom progression, deterioration of the condition and development of lung damage. We provide a detailed review of the analyses of immune checkpoint molecules PD- 1 , TIM-3, LAG-3 CTLA-4, TIGIT, BTLA, CD223, IDO-1 and VISTA on exhausted $T$ cells in patients with asymptomatic to symptomatic stages of COVID-19 infection. Furthermore, this review may help to better understand the pathological $\mathrm{T}$ cell immune response and improve the design of therapeutic strategies for patients with SARS-CoV-2 infection.

\section{Key words}

Inhibitory checkpoint molecules • T cell exhaustion • COVID-19 • SARS-CoV-2

\section{Corresponding authors}

A. Bobčáková, Clinic of Pneumology and Phthisiology, Jessenius Faculty of Medicine in Martin, Comenius University in Bratislava, University Teaching Hospital in Martin, Kollarova 2, 03659 Martin, Slovak Republic. E-mail: abobcakova@gmail.com and M. Jeseňák, Clinic of Pneumology and Phthisiology, Clinic of Paediatrics, Department of Clinical Immunology and Allergology, Jessenius Faculty of Medicine in Martin, Comenius University in Bratislava, University Teaching Hospital in Martin, Kollarova 2, 03659 Martin, Slovak Republic. E-mail: jesenak@gmail.com 


\section{Introduction}

At the end of 2019, a new respiratory coronavirus SARS-CoV-2, which causes COVID-19 disease, was discovered in Wuhan, China (Chan et al. 2020).

Clinical studies have shown that SARS-CoV-2 causes complex changes in cellular immunity, characterized by lymphopenia, neutrophilia, eosinopenia and a distorted distribution of $\mathrm{T}$ cell subpopulations and high plasma concentrations of pro-inflammatory cytokines. Massive cytokine release syndrome, also known as cytokine storm, is observed in polymorbid, elderly cases or in patients with a certain genetic predisposition. A cytokine storm can lead to the progression of the disease to a severe stage with damage to organs, mainly the lungs (Zhang et al. 2020, Shi et al. 2020). Genomic interindividual variability could at least partially explain difference in clinical manifestation of SARS-CoV-2 infection (Vašků et al. 2020).

It is known that cytotoxic $\mathrm{T}$ cells $\left(\mathrm{CD} 8^{+}\right)$activate other cells of the immune system or are directly involved in pathogen destruction and thus prevent the development of infection (Taylor et al. 1986). Detailed studies of the phenotype and function of $\mathrm{CD}^{+}$are necessary in understanding their potential role in the pathophysiology of the disease and the development of therapeutic approaches (Ackermann et al. 2019). Following the induction of effector $\mathrm{T}$ cells with high cytotoxic and proliferative activity, it is essential to prevent excessive host immune responses. T cell activity is regulated by the co-expression of stimulatory and inhibitory receptors (Legat et al. 2013). The inhibitory receptors and their role in the exhaustion of $\mathrm{T}$ cells have been studied in detail, mainly in cancer, chronic viral infection such as hepatitis B (HBV), hepatitis C (HCV) and human immunodeficiency virus (HIV) and active viral infection, including Hantavirus and Ebola (Ackermann et al. 2019, McLane et al. 2019, Kong et al. 2020). The term "T cell exhaustion" is used mostly for effector $\mathrm{T}$ cells with a reduced ability to secrete cytokines and an increased expression of inhibitory receptors. These cells are considered hypofunctional or even dysfunctional effector $\mathrm{T}$ cells. The difference between normal and exhaustion $\mathrm{T}$ cells is in the response to long-term antigen exposure (Blank et al. 2019). However, the exact role and kinetics of co-inhibitory molecules in the early stages of infection have not yet been clarified. Furthermore, it is still unknown how and when $\mathrm{T}$ cell exhaustion and the loss of effector function occurs. Similarly, it is unclear whether cell exhaustion plays a role in the pathophysiology of acute infections (Legat et al. 2013, Diao et al. 2019).

$\mathrm{T}$ cell exhaustion, which often occurs during chronic infection and cancer is also found in patients with COVID-19. Previous experimental studies of $\mathrm{T}$ cell functionality in patients with COVID-19 have shown an upregulation of inhibitory receptors such as programmed cell death protein (PD-1; CD279), T cell immunoglobulin and mucin domain-containing protein 3 (TIM-3; CD366), lymphocyte-activation gene 3 (LAG-3; CD223) and different expression of other immune checkpoint receptors (Table 1). Therefore, it is possible that $\mathrm{T}$ cell exhaustion may play a role in the pathophysiology of COVID-19 infection (Diao et al. 2019). However, the upregulation of inhibitory receptors on $\mathrm{T}$ cells in acute infections may not necessarily relate to their exhaustion. It can be considered a complex immune activation and a balance of excessive immune system reactivity (Legat et al. 2013). Expression of these co-inhibitory receptors has been shown to play a dual role with potentially harmful but also beneficial effects (Abel et al. 2018). Overexpression of inhibitory receptors may prevent a hyperactive host immune response. However, this inhibition of $\mathrm{T}$ cells may also suppress hyperinflammation by down-regulating $\mathrm{T}$ cell effector functions (Butler et al. 2011). Accordingly, in patients with COVID-19, it is crucial to determine the level of co-expression and the extent of the various co-inhibitory receptors (Jubel et al. 2020).

This review offers a systematic summary of the characteristics of $\mathrm{T}$ cell inhibitory checkpoint molecules in association with $\mathrm{T}$ cell exhaustion in patients with COVID-19. In addition, it may help to understand the pathophysiology of the disease and develop immunotherapeutic strategies for COVID-19 treatment. We also aimed to summarize the most important selected immune laboratory parameters with respect to the complications and severity of the disease (Fig. 1) (Bonifacius et al. 2021).

\section{Immune response to COVID-19}

The immune response to infection caused by the new coronavirus is complex dynamic and has not been clearly elucidated. It is biphasic and involves innate and adaptive immunity (Jesenak et al. 2020). After initial responses provided by physical barriers, mucosal and innate immunity, $\mathrm{T}$ and $\mathrm{B}$ cell immunity is gradually 
developed with specific antiviral neutralizing antibodies, which result in rapid elimination of the virus (Rizzo et al. 2020). In severe cases, the course of the infection is more complicated. After the initial phase, which usually has the character of a classic respiratory viral infection, the infection gradually progresses. Secondary bacterial infections form and worsen over the course of the disease. In pneumonia, respiratory insufficiency occurs with the development of ARDS. The severity of lung damage correlates with extensive pulmonary infiltration of neutrophils and macrophages and higher number of these cells in the peripheral blood. Neutrophils are known to be a major source of chemokines and cytokines. It is the cytokine storm which can lead to the development of ARDS. The infection gradually disseminates throughout the body, resulting in sepsis, tissue destruction and multiorgan failure (Wu et al. 2019).

Significant deviations from the reference values have been observed after evaluation of several laboratory parameters in patients with mild and severe courses. Many clinical studies clearly indicate impairment of specific cellular immunity, mainly lymphopenia, differences in number of $\mathrm{T}$ cells $\left(\mathrm{CD}^{+}\right)$, cytotoxic $\mathrm{T}$ cells $\left(\mathrm{CD}^{+}\right)$, helper $\mathrm{T}$ cells $\left(\mathrm{CD} 8^{+}\right)$, $\mathrm{T}$ follicular helper cells, $\gamma \delta-\mathrm{T}$ cells, and regulatory $\mathrm{T}$ cells $\left(\mathrm{T}_{\text {regs }}\right)$. Similarly, changes in B cells have been observed, such as decline of transitional cells, double-negative B cells and antibodysecreting cells (Hasan et al. 2021).

Lymphopenia associated with SARS-CoV-2 infection can be considered an important pathological finding and a sign of disease severity (Diao et al. 2019). Several authors report that lymphopenia affects $\mathrm{CD}^{+}{ }^{+} \mathrm{T}$ cells, $\mathrm{CD}^{+} \mathrm{T}$ cells, B cells and NK cells (KuriCervantes et al. 2020, Liao et al. 2020, GiamarellosBourboulis et al. 2020). In a comparison of all the analyses, the highest proportion of patients with lymphopenia was observed in a study by Guan et al. (2020). At admission, significant lymphocytopenia was observed in nearly $83.2 \%$ of a total cohort of 1.099 patients. It has been observed that lymphocytopenia occurred in $96.1 \%$ of patients with a severe course of the disease, compared to $80.4 \%$ of patients with less symptomatic or asymptomatic infection (Guan et al. 2020).

In a retrospective cohort study, Wu et al. (2020) observed lymphocytopenia in $64 \%$ of 201 patients with confirmed COVID-19 pneumonia (Wu et al. 2020). Regarding the above-mentioned results of the analyses, the percentage of lymphocytes was proposed as a predictive biomarker of disease severity (Tan et al. 2020).
Detailed analysis of two major subtypes of $\mathrm{T}$ cells revealed increased levels of $\mathrm{CD}^{+}$naïve $\mathrm{T}$ cells $\left(\mathrm{CD}^{+} \mathrm{CD}^{+} \mathrm{CD}^{+} 5 \mathrm{RA}^{+}\right)$in severe cases, whereas the percentage of memory helper $\mathrm{T}$ cells $\left(\mathrm{CD}^{+} \mathrm{CD}^{+}\right.$ $\mathrm{CD}^{2} \mathrm{RO}^{+}$) was reduced in samples of peripheral blood patients with COVID-19. The reduction of $\mathrm{T}_{\text {regs }}\left(\mathrm{CD}^{+}\right.$ $\mathrm{CD} 4^{+} \mathrm{CD} 25^{+} \mathrm{CD} 127^{\text {low }}$ ) in SARS-CoV-2 infection also contributes to an excessive inflammatory response (Guan et al. 2020).

In addition, examination and evaluation of immune parameters can be a suitable prognostic marker for the early diagnosis of unexpected complications and different degrees of disease severity. Similarly, a better understanding of changes in the immunoprofile of patients with COVID-19 may lead to new possibilities in therapeutic intervention or immune support (Jesenak et al. 2020).

Besides the above-mentioned changes which occur in the immune profile, another possible consequence of insufficient immune control over COVID-19 pneumonia may be T cell exhaustion and increased expression of the inhibitory immune checkpoint molecules on their surfaces (Zheng et al. 2020). To design therapeutic strategies for the treatment of COVID19 , it is necessary to investigate the signalling pathways of the inhibitory checkpoint molecules which regulate the immune system (Bersanelli et al. 2020).

\section{PD-1}

Programmed cell death protein 1 (PD-1; CD279) is a protein which is present on the surface of $\mathrm{T}$ cells and pre-B cells and acts as an immune checkpoint molecule. After binding PD-1 of soluble ligands PD-L1 (B7-H1; CD274) and PD-L2 (B7-DC; CD273), they commute to the downregulation of excessive immune response, and thus maintains self-tolerance by suppressing the inflammatory activity of $\mathrm{T}$ cells. This mechanism protects an organism against the development of autoimmune diseases. PD-1 also causes the escape of cancer cells from the host immune system control (Syn et al. 2017). Furthermore, PD-1 supports apoptosis of specific T cells in lymph nodes. However, it reduces the apoptosis of regulatory $\mathrm{T}$ cells (anti-inflammatory, suppressive $\mathrm{T}$ cells) and thus indirectly increases the regulation of immune cells (Fife et al. 2011). Increased expression of PD-1 is one of the main indicators of T cell exhaustion (e.g. in chronic infection or cancer) (Syn et al. 2017, Pauken et al. 2015). 
Table 1. Mechanism of action of immune checkpoint inhibitors (ICI) in COVID-19.

\begin{tabular}{|c|c|c|c|}
\hline Molecule & & $\begin{array}{c}\text { Pathway of ICI in global immune responses } \\
\text { during SARS-CoV-2 infection }\end{array}$ & References \\
\hline \multirow[t]{5}{*}{ PD-1 } & $\uparrow$ & Expression on $\mathrm{CD}^{+} \mathrm{T}$ cells in severe cases & Kuri-Cervantes et al. 2020 \\
\hline & $\uparrow$ & Expression on $\mathrm{CD}^{+}$and $\mathrm{CD} 8^{+}$in severe cases & Diao et al. 2019 \\
\hline & $\uparrow$ & Expression on $\mathrm{CD}^{+}$and $\mathrm{CD} 8^{+}$in non-survivors & Bobcakova et al. 2021 \\
\hline & $\uparrow$ & Concentration sPD-1 in severe cases & Kong et al. 2020 \\
\hline & $\uparrow$ & Expression on NK cells in critical cases & Demaria et al. 2020 \\
\hline \multirow[t]{5}{*}{ TIM-3 } & $\uparrow$ & Expression on $\mathrm{CD}^{+}$in non-survivors & Shahbazi et al. 2021 \\
\hline & $\uparrow$ & Expression on $\mathrm{CD}^{+}$and $\mathrm{CD}^{+}$in severe cases & Martín-Quirós et al. 2021 \\
\hline & $\uparrow$ & $\begin{array}{c}\text { Expression on } \mathrm{CD} 4+, \mathrm{CD} 8+\text { and NK cells in } \\
\text { severe cases }\end{array}$ & Varchetta et al. 2021 \\
\hline & - & $\begin{array}{l}\text { No significant difference in expression between } \\
\text { survivors and non-survivors }\end{array}$ & Bobcakova et al. 2021 \\
\hline & $\uparrow$ & Expression on $\mathrm{CD}^{+}$and $\mathrm{CD} 8^{+}$in severe cases & Herrmann et al. 2020 \\
\hline \multirow[t]{5}{*}{ LAG-3 } & $\uparrow$ & Expression in macrophages and $\mathrm{CD}^{+}$from BALF & Saheb Sharif-Askari et al. 2021 \\
\hline & $\uparrow$ & $\begin{array}{c}\text { Expression of mRNA LAG-3 in nasopharyngeal } \\
\text { swabs and lung autopsies }\end{array}$ & Saheb Sharif-Askari et al. 2021 \\
\hline & $\uparrow$ & Concentration sLAG-3 in severe cases & Kong et al. 2020 \\
\hline & $\uparrow$ & $\begin{array}{c}\text { Expression on } \mathrm{CD}^{+} \text {and } \mathrm{CD} 8^{+} \mathrm{T} \text { cells in different } \\
\text { severity groups }\end{array}$ & Herrmann et al. 2020 \\
\hline & $\uparrow$ & Expression on $\mathrm{CD}^{+}$in mild and severe cases & Rendeiro et al. 2020 \\
\hline \multirow[t]{3}{*}{ CTLA-4 } & $\uparrow$ & Expression on $\mathrm{CD}^{+}$and $\mathrm{T}_{\text {regs }}$ & Jeannet et al. 2020 \\
\hline & - & $\begin{array}{l}\text { No significant differences between mild versus } \\
\text { severe cases }\end{array}$ & Zheng et al. 2020 \\
\hline & $\uparrow$ & Serum levels of sCTLA-4 & Kong et al. 2020 \\
\hline \multirow[t]{9}{*}{ TIGIT } & - & $\begin{array}{l}\text { No difference in expression between healthy } \\
\text { controls, mild and severe cases }\end{array}$ & Herrmann et al. 2020 \\
\hline & - & $\begin{array}{l}\text { Expression on } \mathrm{CD}^{+} \text {cells and } \mathrm{CD}^{+} \text {cells was } \\
\text { similar to that of healthy controls }\end{array}$ & Schultheiß et al. 2020 \\
\hline & - & $\begin{array}{l}\text { Expression on } \mathrm{CD}^{+} \text {and } \mathrm{CD}^{+} \text {was lower in non- } \\
\text { ICU than in healthy controls and ICU patients }\end{array}$ & Gutiérezz-Bautista et al. 2020 \\
\hline & $\uparrow$ & Expression on $\mathrm{CD} 4^{+}$in mild and severe cases & \\
\hline & & Expression on $\mathrm{CD}^{+}$in healthy and mild cases & Zheng et al. 2020 \\
\hline & $\uparrow$ & compared to severe patients & \\
\hline & $\uparrow$ & $\begin{array}{l}\text { Expression on } \mathrm{CD}^{+} \text {cells in hospitalized and non- } \\
\text { hospitalized COVID-19 patients compared to } \\
\text { healthy controls }\end{array}$ & Files et al. 2021 \\
\hline & $\uparrow$ & $\begin{array}{c}\text { Expression on } \mathrm{CD}^{+} \text {over time in non-hospitalized } \\
\text { patients }\end{array}$ & \\
\hline & $\downarrow$ & $\begin{array}{c}\text { Expression on } \mathrm{CD}^{+} \mathrm{TCM}, \mathrm{Ki} 67^{+} \mathrm{CD}^{+} \text {and } \\
\mathrm{Ki} 67^{+} \mathrm{CD}^{+} \text {in } \mathrm{COVID}-19 \text { patients }\end{array}$ & Breton et al. 2021 \\
\hline \multirow[t]{2}{*}{ BTLA } & $\uparrow$ & $\begin{array}{c}\text { Expression on } \mathrm{CD}^{+} \text {and } \mathrm{CD} 8^{+} \text {in COVID-19 } \\
\text { patients with active disease }\end{array}$ & Schultheiß et al. 2020 \\
\hline & $\downarrow$ & $\begin{array}{l}\text { Expression in transient and effector memory CD } 8^{+} \\
\text {cells pronounced less significantly in COVID-19 } \\
\text { patients than in healthy controls }\end{array}$ & Herrmann et al. 2020 \\
\hline
\end{tabular}




\begin{tabular}{lccc}
\hline CD224 & $\uparrow$ & $\begin{array}{c}\text { Expression on } \mathrm{CD}^{+} \text {and } \mathrm{CD} 8^{+} \text {in severe and mild } \\
\text { cases }\end{array}$ & Li et al. 2020 \\
\hline VISTA & $\uparrow$ & $\begin{array}{c}\text { Expression on } \mathrm{CD} 4^{+} \text {and } \mathrm{CD} 8^{+} \text {in mild and severe } \\
\text { COVID-19 patients }\end{array}$ & Rendeiro et al. 2020 \\
\hline IDO & $\uparrow$ & $\begin{array}{c}\text { Percentage in severe versus both mild COVID-19 } \\
\text { patients and healthy donors }\end{array}$ & Tomić et al. 2021 \\
& & $\begin{array}{c}\text { Expression on monocytes and polymorphonclear } \\
\text { myeloid-derived suppressor cells in severe patients }\end{array}$ & \\
\hline
\end{tabular}

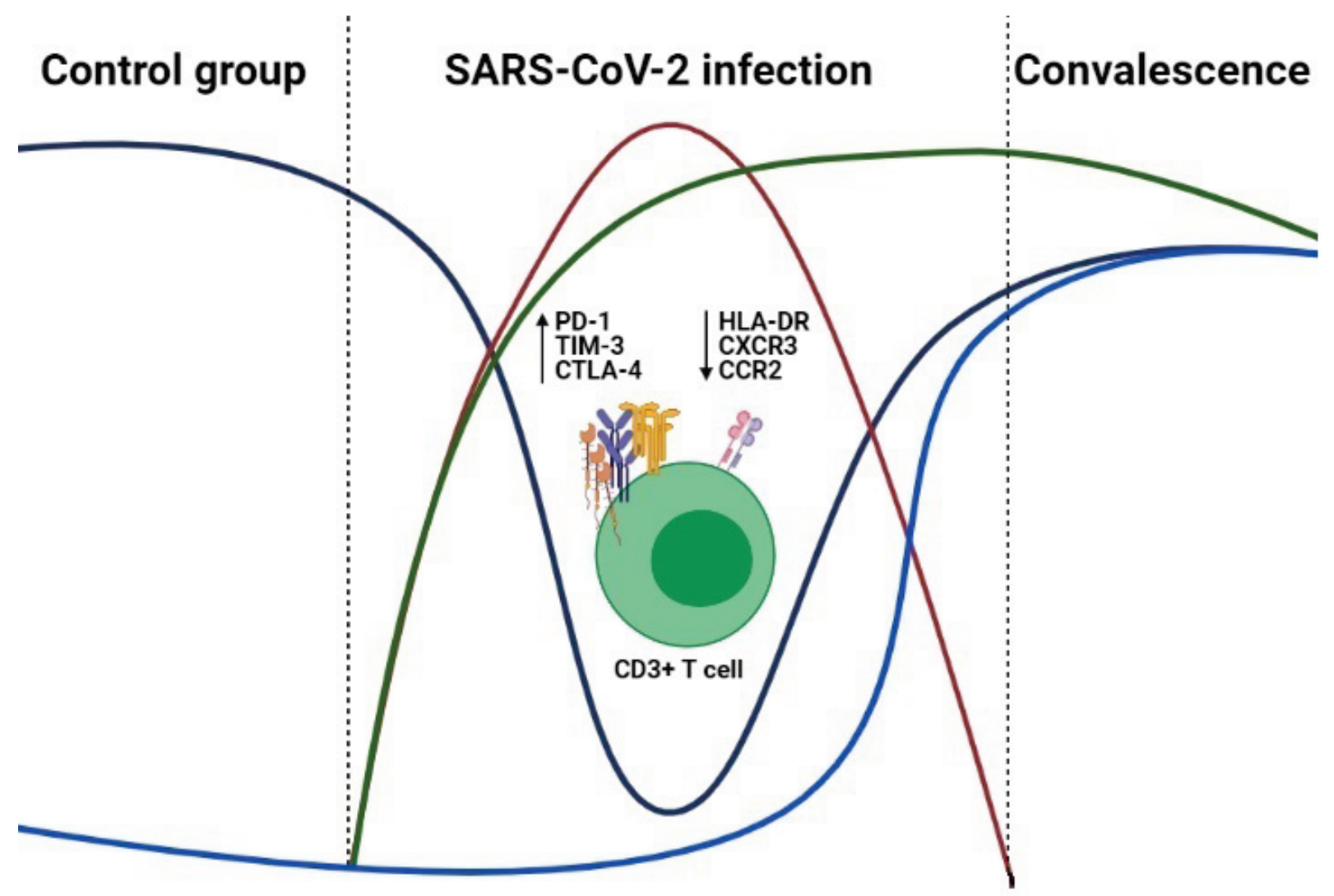

\section{Active $T$ cells}

Negative SARSCoV-2 antibodies

\section{Low perecentage} of HuCoV-specific $T$ cells

\section{Exhausted T cells}

Positive anti-SARS-CoV-2
antibodies Low percentage of SARS-CoV-2 specific $T$ cells

\section{Recovered T cells}

Slow decrease of antiSARS-CoV-2 antibodies

High levels of antiviral $T$ cells

\section{- Viral load - SARS-CoV-2 T cells $=$ Anti-SARS-CoV-2 antibodies $=$ T cell functionality}

Fig. 1. Graphical representation of $T$ cell functionality and immune response during SARS-CoV-2 infection. The immune response is dysregulated and involves innate and adaptive immunity. During the severe-to-critical form of SARS-CoV- 2 infection, an impaired cellular immune response is observed: decreased T cells including $\mathrm{CD}^{+}$and $\mathrm{CD} 8^{+}$; dysfunctional $\mathrm{T}$ cells express marker of exhaustion PD-1, TIM-3, LAG-3; anti-SARS-CoV-2 antibodies and SARS-CoV-2 specific memory T cells (huCoV-human coronavirus) are progressively produced (adapted from Bonifacius et al. 2021). (Created in BioRender.com). 
Considering physiological conditions, PD-1 negatively regulates the immune response. Signal transmission occurs only if it is associated with a $\mathrm{T}$ cell or a $\mathrm{B}$ cell receptor. PD-1 inhibits the PI3K/AKT/mTOR intracellular signalling pathway and MAP kinase pathway (Ras/MEK/Erk; inhibition of Ras protein). Inhibition of these signalling pathways leads to a blockade of the cell cycle. It is known that inhibition of the PI3K pathway stimulates apoptosis (Parry et al. 2005). This leads to a reduction in the expression of the apoptosis inhibitor B-cell lymphoma-extra large (BcL-xl), which is otherwise expressed in costimulatory signaling via CD28 (Chemnitz et al. 2004). Blockade of the $\mathrm{PI} 3 \mathrm{~K} / \mathrm{AKT} / \mathrm{mTOR}$ pathway also results in activation (absence of inhibitory phosphorylation) of the transcription factor forkhead box protein $\mathrm{O} 1$ (FoxO1), leading to an increased expression of PD-1 by positive feedback. This contributes to the exhausted phenotype of T cells (Staron et al. 2014).

The role of PD-1/PD-L1 axis have been studied especially in cancer immunotherapy. PD-L1, the ligand for PD-1, is highly expressed in several types of cancer such as lung cancer, kidney cancer or melanoma. Therefore, the role of PD-1 in cancer immune evasion is well established. Inhibition of the interaction between PD-1 and PD-L1 may increase T cell-mediated immune response and preclinical antitumor activity. Pembrolizumab and nivolumab, monoclonal antibodies targeting PD-1 receptor, are used in clinical practice to treat metastatic melanoma, non-small cell lung cancer, head and neck squamous cell carcinoma, urothelial carcinoma and Hodgkin lymphoma (Alsaab et al. 2013).

In chronic viral infections, the principal role of PD-1 in the regulation of $\mathrm{T}$ cell exhaustion was welldefined in profiling of the gene expression of virusspecific $\mathrm{CD}^{+} \mathrm{T}$ cells in chronic lymphocytic choriomeningitis (LCMV) (Barber et al. 2006).

The effect of dysfunction or physical destruction of antigen-specific $\mathrm{T}$ cells has been also found in HIV infection. PD-1 expression on $\mathrm{CD}^{+} \mathrm{T}$ cells has been positively correlated with high viral load, disease progression, decreased $\mathrm{CD}^{+}$counts, and impaired of $\mathrm{CD}^{+} \mathrm{T}$ cell function. In vitro studies have reported that blocking of the PD-1 signaling pathway has led to the recovery of $\mathrm{T}$ cell functions (Day et al. 2006). Control of the immune system also improved by increasing $\mathrm{T}$ cell proliferation and cytokine production (Palmer et al. 2013). In addition, after in vivo administration of antiPD-L1 antibodies, the percentage of $\mathrm{CD}^{+}$and $\mathrm{CD}^{+} \mathrm{T}$ cells increased. It led to a blockade of viral replication in HIV-infected mice (Di Cosimo et al. 2020).

Importantly, it has been demonstrated that in SARS-CoV-2 alveolar infection, early anti-PD-1 therapeutic intervention is required and may decrease the number of exhausted $\mathrm{T}$ cells and block the development of ARDS (Fig. 2) (Vivarelli et al. 2021).

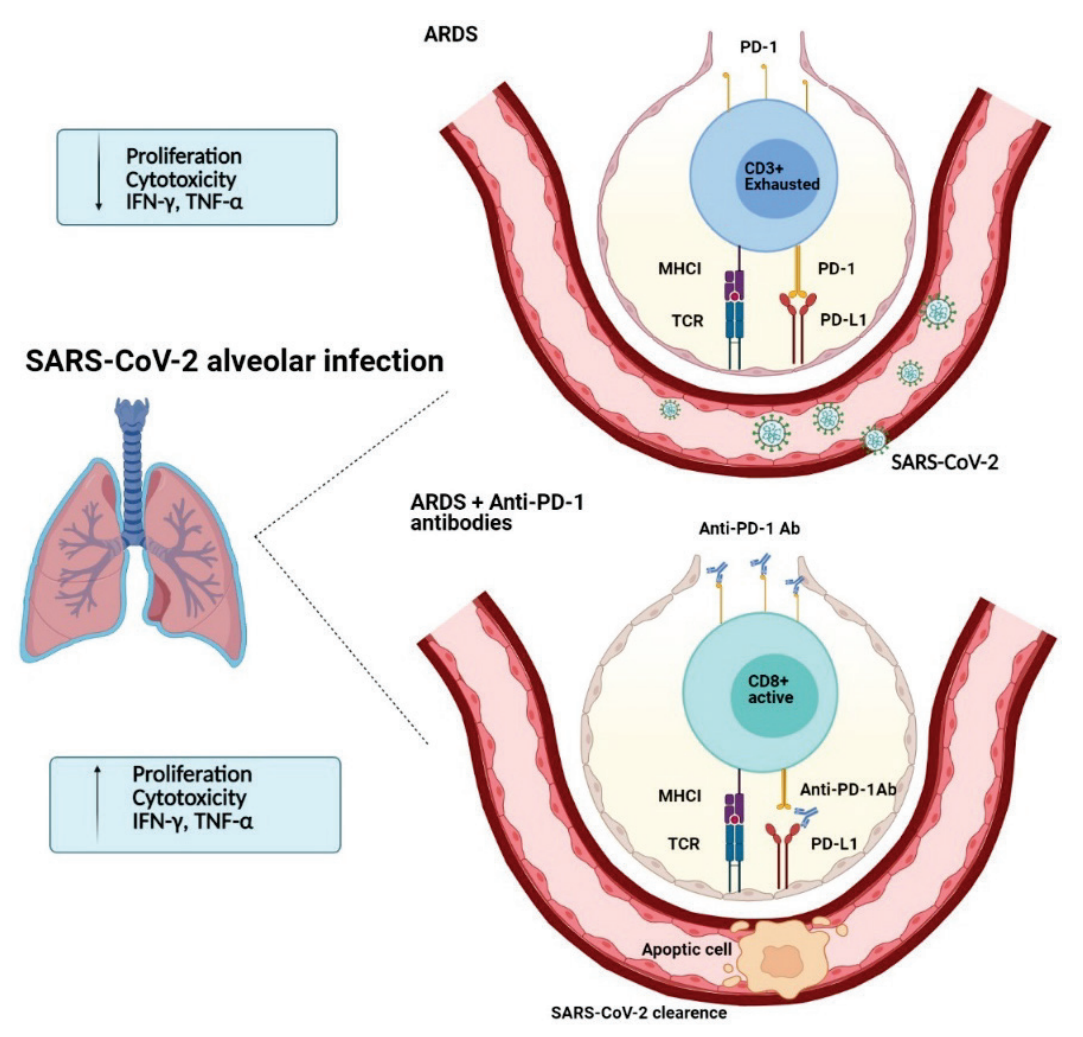

Fig. 2. SARS-CoV-2 alveolar infection in severe-to-critical degree of the disease could promote ARDS. Immunotherapy with anti-PD-1 antibodies can recover the function of cytotoxic $T$ cells and maintain optimal viral clearance (adapted from Vivarelli et al. 2021). (Created in BioRender.com). 
Kuri-Cervantes et al. (2020) observed increased activation of $\mathrm{CD}^{+}$and $\mathrm{CD} 8^{+} \mathrm{T}$ cells in patients with severe course of COVID-19 compared to the control groups. In summary, the frequency of PD-1 on $\mathrm{CD}^{+} \mathrm{T}$ cells, but not $\mathrm{CD} 8^{+} \mathrm{T}$ cells, were higher in the severe group of COVID-19 than in the healthy donors (HD). Activation of $\mathrm{CD}^{+}$and $\mathrm{CD} 8^{+} \mathrm{T}$ cells in recovered patients was equivalent to the HD group. In mild or severe COVID-19, PD- $1^{+} \mathrm{CD}^{+} \mathrm{T}$ cells, but not PD- $1^{+} \mathrm{CD} 8^{+}$cells, correlated with donor age. The percentage of $\mathrm{PD}^{+} \mathrm{CD}^{+} \mathrm{T}$ cells also correlated with acute physiology and chronic health evaluation (APACHE) III score (Kuri-Cervantes et al. 2020). Another retrospective study analysed 522 patients with COVID-19. The percentage of total $\mathrm{CD} 8^{+} \mathrm{CD}^{+} \mathrm{T}$ cells was significantly lower, especially in patients who required intensive care unit (ICU) care. The study also examined whether $\mathrm{CD}^{+}$and $\mathrm{CD}^{+}$had exhaustion phenotypes. Flow cytometry analysis showed that compared to healthy individuals, patients with severe COVID-19 syndrome had considerably high percentages of PD- $1^{+} \mathrm{CD}^{+}$and PD- $1^{+} \mathrm{CD} 4^{+}$. PD- 1 expression on the surface of $\mathrm{T}$ cells was also monitored in three patients during hospitalization. These patients had a very low percentage of $\mathrm{PD}-1$ on $\mathrm{CD}^{+}$and $\mathrm{CD} 8^{+}$in the initial stage of the disease. However, the expression of PD- 1 on $\mathrm{CD} 8^{+}$ increased gradually, depending on the disease progression and ICU period stages. Otherwise, the percentage of PD- 1 on $\mathrm{CD}^{+} \mathrm{T}$ cells was not obviously affected during disease progression. These results clearly indicated that $\mathrm{T}$ cells are exhausted in patients with COVID-19 during SARS-CoV-2 infection (Diao et al. 2019).

A Slovak study demonstrated the expression of immune cell exhaustion markers in 21 patients sorted into four groups according to disease severity. Overall, the results showed notably lymphopenia and the depletion of $\mathrm{CD}^{+}, \mathrm{CD}^{+}, \mathrm{CD}^{+}$and $\mathrm{CD} 19^{+} \mathrm{T}$ cell subpopulations in correlation with the progress of the disease. Patient recovery was correlated with a significant increase in $\mathrm{CD}^{+}$and $\mathrm{CD}^{+} \mathrm{CD}^{+} \mathrm{T}$ cells. Significantly higher expression levels of PD- 1 on $\mathrm{CD} 4^{+}$and $\mathrm{CD} 8^{+}$were found in non-survivors than in survivors. Patients with a severe degree of infection which led to death also had a significantly higher percentage of activated $\mathrm{CD} 38^{+} \mathrm{CD} 8^{+}$cells and a lower proportion of $\mathrm{CD} 38^{+} \mathrm{HLA}-$ $\mathrm{DR}^{+} \mathrm{CD}^{+}$. Clinical improvement was associated with a significantly decreased expression of $\mathrm{CD} 38^{+} \mathrm{CD} 8^{+}$ $\mathrm{T}$ cells. Furthermore, AUC values derived from the ROC curve were also analysed. The highest AUC values within univariate and multivariate logistic regression were recorded for $\mathrm{CD} 38^{+}$on $\mathrm{CD} 8^{+}$and $\mathrm{PD} 1$ on $\mathrm{CD} 4^{+} \mathrm{T}$ cells. This suggests that co-expression of $\mathrm{CD} 38^{+}$on $\mathrm{CD} 8^{+}$and PD-1 on $\mathrm{CD}^{+} \mathrm{T}$ cells or their independent expression may represent a promising predictive biomarker of unfavorable prognosis of COVID-19 (Bobcakova et al. 2021).

Although above mentioned membrane-bound checkpoint inhibitors are of major importance and have become the scientific topic worldwide, concentration of their soluble isoforms should also be of interest, as they are either the product of membrane cleavage or alternative mRNA splicing and participate in competitive regulation of their membrane-bound counterparts (Gu et al. 2018).

A Chinese study investigated the relationship between soluble checkpoint molecules and the progression of COVID-19. The immune profile was evaluated in 109 patients with a confirmed diagnosis of COVID-19. The patients were divided into groups according to clinical symptoms and disease severity. Serum concentrations of 14 soluble checkpoint inhibitors (sBTLA, sGITR, sHVEM, SIDO, sLAG-3, sPD-1, sPD-L1， sPD-L2， sTIM-3， sCD28， sCD80, s4-1BB, SCD27 and sCTLA-4) were evaluated within three days of admission to the hospital. It was found, that serum levels of all tested molecules, except PD-L2, were significantly higher in critical cases than in mild-tomoderate cases and asymptomatic groups. Additionally, dynamic analysis showed that 11 molecules (sGITR, s4-1BB, sTIM-3, sCD27, sLAG-3, sPD-1, sCD28, SCTLA-4, sBTLA, sHVEM and sCD80) had higher concentrations in patients with a severe course of the disease compared to moderate cases during hospitalization. The result of flow cytometric analysis was higher levels of the glucocorticoid-induced tumor necrosis factor receptor (GITR), CD137, TIM-3, CD27, PD-1, and LAG- 3 on $\mathrm{CD}^{+}$and $\mathrm{CD} 8^{+} \mathrm{T}$ cells in critical patients than in milder patients (Kong et al. 2020).

\section{TIM-3}

TIM-3 is a negative regulator of immune response, and together with PD-1 and lymphocyte activation gene 3 protein (LAG-3), is highly expressed on dysfunctional or exhausted $\mathrm{CD} 8^{+} \mathrm{T}$ cells (Blackburn et al. 2009). The key tasks of TIM-3 are the inhibition of Th1 responses and the expression of cytokines such as INF- $\gamma$ and TNF. The role of TIM- 3 in of T cell exhaustion was 
first identified in patients with HIV infection (Jones et al. 2008). As a checkpoint receptor, TIM-3 controls T cell response against different chronic viral infections such as HBV, HCV and Friend virus (Takamura et al. 2010).

The study of co-expression of exhaustion markers PD-1, TIM-3 and CD39 on $\mathrm{CD} 8^{+}$involved 44 patients, specifically 17 subjects in a critical group, 27 patients in a non-critical group, and 14 healthy controls. Their findings showed that the percentage of $\mathrm{CD}^{+} \mathrm{T}$ cells was significantly lower in patients with mild and severe COVID-19 pneumonia than in a healthy group (Shahbazi et al. 2021). This finding is consistent with a previous report and confirms that the percentage of T cells could be used as a diagnostic marker of COVID-19 (Chen et al. 2020). In this univariate analysis, critical patients had a higher number of $\mathrm{CD} 8^{+} \mathrm{TIM}^{-} 3^{+}$ than patients with a mild course of the disease or the healthy controls. Similarly, the percentage of $\mathrm{CD}^{+} \mathrm{TIM}^{+} 3^{+}$cells was significantly higher in noncritical patients than in a healthy subjects. This analysis showed that SARS-CoV-2 activates high cytotoxic activity of $\mathrm{T}$ lymphocytes in the initial stage of the infection, which continues in their exhaustion. Presumably, the excessive depletion of $\mathrm{CD}^{+} \mathrm{T}$ cells in critical patients attenuates the cellular response to SARSCoV-2 (Shahbazi et al. 2021).

An interesting case report was presented by Martín-Quirós et al. (2021), who analysed the Galactin9/TIM-3 axis in different clinical courses of SARS-CoV-2. The cohort involved 57 patients, including one married couple. The married couple was exposed to the same dose of SARS-CoV-2 before the onset of the infection and had the same clinical characteristics with bilateral interstitial pneumonia, respiratory failure and almost similar laboratory findings. Patient 1 was a 60-year-old overweight male and his anamnesis showed hypertension, type 2 diabetes and hemochromatosis type 1 with no hepatic or systemic involvement. The course of the infection was moderate, but the patient was hospitalized after 10 days due to worsening of dyspnea. The physical examination showed tachycardia, moderate tachypnea and disseminated crackling rales on pulmonary auscultation. An RT-PCR for SARS-CoV-2 confirmed the COVID-19 infection. Patient 2 was a non-obese 60 -year-old woman without previous comorbidities. The course of infection progressed with moderate symptoms, such as asthenia myalgia, low-grade fever, and nausea with episodes of vomiting. Similarly, COVID-19 was confirmed by SARS-CoV-2 RT-PCR. The immune profile of patients was repeatedly monitored by flow cytometry until the exitus of patient 1 and the discharge of patient 2. The expression of TIM- 3 on $\mathrm{CD}^{+}$cells was significantly increased in patient 1 , while in patient 2 , the percentage of TIM- 3 was the same as in the control group. Low levels of $\mathrm{CD}^{+}$and $\mathrm{CD}^{+}$subpopulations were confirmed in the critical patients (patient 1) and remained unchanged throughout the infection. In addition, TIM-3 levels were remarkably higher on the $\mathrm{CD}^{+}$and $\mathrm{CD} 8^{+} \mathrm{T}$ cells of patient 1 than patient 2. Analysis of soluble Gal-9 in plasma at the onset of infection were increased in both patients. However, eight days after the initial stage of the infection, a significantly different level of sGal- 9 was observed between patients 1 and 2. This difference was correlated with different clinical disease progression. Levels of sGal-9 were significantly higher in non-surviving patients than survivors. The data obtained suggest that the concentration of sGal- 9 and the expression of TIM-3 on $\mathrm{T}$ cells could represent a prognostic biomarker for patients at high risk of developing secondary bacterial infections, even sepsis (Martín-Quirós et al. 2021).

An extensive analysis of the immune response was performed in 32 patients with radiologically confirmed mild-to-severe pneumonia and a SARS-CoV-2 RNA positive nasopharyngeal swab. It has been found that in COVID-19 infection, not only T cells but also NK cells showed an exhausted phenotype. The absolute count of NK cells was significantly lower in patients with COVID-19 while the control group had the reference number. In brief, increased expressions of CD69 and TIM- 3 on NK cells, $\mathrm{CD}^{+}$and $\mathrm{CD}^{+} \mathrm{T}$ cells were observed in patients with poor outcome compared to healthy subjects. NK cell exhaustion was confirmed by increased frequencies of $\mathrm{PD}-1^{+}$and reduced frequencies of natural killer group 2 member D (NKG2D), DNAX accessory molecule-1 (DNAM-1) and sialic acid-binding Ig-like lectin 7 (Siglec-7) expressing NK cells, associated with a reduced ability to secrete IFN- $\gamma$ (Varchetta et al. 2021). In addition, Demaria et al. (2020) identified a depleted NK cells phenotype by increased PD-1 expression on NK cells in critical patients (Demaria et al. 2020). Increased $\mathrm{CD} 8^{+} \mathrm{T}$ cell frequencies were also observed in 7 patients who underwent regular testing after recovery. Simultaneously, there was a significant reduction in expression of TIM- 3 on $\mathrm{CD} 8^{+}$and NK cells. By contrast, no functional renewal of the NK cells was observed, suggesting that functional changes in COVID-19 were more pervasive than expected. In 
general, this study confirmed that patients with unfavorable prognosis have functionally exhausted NK cells and hyperactivated/exhausted T cells (Varchetta et al. 2021).

In another retrospective observational study that contributed to characterization of the immunological profile, a significantly increased PD-1 expression was observed on $\mathrm{CD}^{+}$and $\mathrm{CD}^{+}{ }^{+} \mathrm{T}$ cells in non-survivors compared to survivors. However, no significant difference in TIM-3 expression was observed, which showed possible reversibility of immune paralysis in the most severe group of patients with COVID-19. Expression of TIM-3 on both $\mathrm{CD}^{+}$and $\mathrm{CD}^{+}$was significantly reduced during clinical recovery (Bobcakova et al. 2021).

\section{LAG-3}

Lymphocyte-activation gene 3 (LAG-3; CD223) is a CD4-related, activation-induced cell surface molecule which is expressed upon antigen stimulation on activated $\mathrm{CD}^{+}$and $\mathrm{CD}^{+} \mathrm{T}$ cells (Huard et al. 1995), NK cells (Triebel et al. 1990), B cells (Kisielow et al. 2005) and plasmacytoid dendritic cells (Workman et al. 2009). The expression of LAG-3 on DCs may result in signalling pathways which upregulate TNF- $\alpha$ and IL-12. Sharing several structural similarities with CD4, it also binds to MHC class II molecules, but with significantly higher affinity, possibly acting as a natural competitor of CD4 (Huard et al. 1995), and was shown to downregulate the expansion of activated T cells (Workman et al. 2002). LAG-3 negatively regulates cellular proliferation, activation, and homeostasis of T cells (Workman et al. 2003, Huang et al. 2004).

In 2010, LAG-3 was defined as a marker of CD8 ${ }^{+}$ $\mathrm{T}$ cell depletion in lymphocytic choriomeningitis (LCM). However, in this case, LAG-3 did not significantly contribute to $\mathrm{T}$ cell exhaustion on it is own (Lucas et al. 2011). Multiple transcriptional regulators such as thymocyte selection-associated high mobility group box protein (TOX), interferon regulatory factor 4, nuclear receptor subfamily 4 group A (NR4A), B lymphocyteinduced maturation protein-1, and nuclear factor of activated T cells (NFAT) are also known to be involved in $\mathrm{T}$ cell depletion. Based on preclinical data, the therapeutic benefit of agents which block or stimulate LAG-3 functions is expected, especially in the treatment of cancer and autoimmune diseases in combination with substances aimed at inhibiting PD-1 (Maruhashi et al. 2020).
Currently, only a few studies have examined the role of LAG-3 in SARS-CoV-2 infection. A transcripttomics study and subsequent in silico analysis evaluated the expression profiles of 38 selected immune inhibitor receptors (IRs) during SARS-CoV-2 infection. The expression levels of IRs were analyzed in nasopharyngeal swabs (NPSs) in 430 RT-PCR-confirmed COVID-19 patients and 54 negative controls by RNA sequencing. RNA-seq analyses revealed an overall upregulation of IRs mRNA during the acute phase of SARS-CoV-2 infection. Accordingly, eight genes (BTLA, LAG3, FCGR2B, PDCD1, CEACAM1, CTLA4, CD72, and SIGLEC7) shared by NPSs and autopsies were more expressed in autopsies and directly correlated with viral levels. The upregulation of PD-1, CTLA4, BTLA and LAG-3 was also observed on macrophages and $\mathrm{CD}^{+} \mathrm{T}$ cells isolated from bronchoalveolar lavage fluid in patients with severe COVID-19. The observed upregulation of LAG-3 mRNA in NPS may cause a negative feedback mechanism in response to immune activation, while increased expression of LAG-3 in lung autopsies and macrophages could most likely cause terminal differentiation of these cells (Saheb SharifAskari et al. 2021). Thus, epigenetic modulation of immune regulatory genes has also been reported in other viral infections and may represent a mechanism of SARS-CoV-2 immune escape (Menachery et al. 2018). Activation of these IRs could suppress innate and adaptive immune responses, resulting in a defect in viral clearance (Saheb Sharif-Askari et al. 2021). A study of soluble checkpoint molecules in 109 patients with confirmed COVID-19 infection showed that sLAG-3 was persistently higher in severe cases than in moderate cases during hospitalization. Simultaneously, flow cytometric analysis revealed greater levels of LAG-3 on $\mathrm{CD}^{+}$and $\mathrm{CD}^{+} \mathrm{T}$ cells in severe case patients than in those from mild-to-moderate patients (Kong et al. 2020).

An increased expression of LAG-3 and TIM-3 on both $\mathrm{CD}^{+}$and $\mathrm{CD} 8^{+} \mathrm{T}$ cells was observed across all severity groups of COVID-19 patients, with the level of their expression depending on disease severity; higher expression was described in severe cases than in cases with milder forms. Recovery was associated with a rapid decline in PD-1, Tim-3 and LAG-3 expression. Compared to healthy controls, significantly higher frequencies of single positive $\mathrm{PD} 1^{-} \mathrm{LAG} 3^{+}$and $\mathrm{PD} 1^{-}$ $\mathrm{Tim}^{+} \mathrm{CD}^{+}$and $\mathrm{CD}^{+}$cells, and double positive $\mathrm{PD}^{+} \mathrm{LAG}^{+}$and $\mathrm{PD} 1^{+} \mathrm{Tim}^{+}{ }^{+} \mathrm{CD} 4^{+}$and $\mathrm{CD} 8^{+}$cells were present. The level of activation markers expression 
(CD69, CD38 and HLA-DR) was related to the co-expression of inhibitory receptors (PD1, LAG-3, TIM-3) (Herrmann et al. 2020).

A study by Rendeiro et al. (2020) revealed that both mild and severe COVID-19 patients had increased frequencies of LAG-3 positive $\mathrm{CD}^{+}$cells (Rendeiro et al. 2020). It therefore remains necessary to investigate whether upregulation of inhibitory receptors on $\mathrm{T}$ cells may have a beneficial or adverse effect on the course of infection (Dookie et al. 2020). There are also discussions whether $\mathrm{T}$ cell exhaustion can occur during acute viral infections, as expression of inhibitory receptors is also induced by $\mathrm{T}$ cell activation and differentiation. However, LAG-3, either alone or in combination with other immune checkpoints, is an ideal target for immunotherapy (Legat et al. 2013).

\section{CTLA-4}

Cytotoxic T Lymphocyte Antigen 4 (CTLA-4; CD152) is expressed on both $\mathrm{CD} 4^{+}$and $\mathrm{CD} 8^{+}$cells, and its interaction with $\mathrm{CD} 80$ and $\mathrm{CD} 86$ on antigen presenting cells (APCs) is responsible for the inhibition of $\mathrm{T}$ cell responses, in contrast to $\mathrm{CD} 28$, which, sharing the same ligands CD80 and CD86, in turn leads to stimulation (Rowshanravan et al. 2018).

Only a small number of studies have analyzed this inhibitory receptor in COVID-19 patients. Jeannet et al. (2020) noticed a transient increase in CTLA-4 expression on $\mathrm{CD}^{+}$during the first three days of ICU stay and its over-expression on regulatory $\mathrm{T}$ cells (Jeannet et al. 2020). However, CTLA-4 expression on $\mathrm{CD}^{+}$cells did not differ from the healthy controls. By contrast, in a study by Zheng HY et al. (2020), no significant differences between CTLA-4 expression in healthy versus mild, healthy versus severe, nor mild versus severe COVID-19 patients were observed (Zheng et al. 2020).

A Chinese study compared serum concentrations of soluble forms of 14 checkpoint inhibitors (sBTLA, sGITR, sHVEM, sIDO, sLAG-3, sPD-1, sPD-L1, sPD-L2, sTIM-3, sCD28, sCD80, s4-1BB, sCD27, and sCTLA-4) in patients with asymptomatic versus mild-tomoderate and severe-to-critical COVID-19 patients. Severe-to-critical cases had significantly higher serum levels of all tested molecules, with the exception of PD-L2; this pattern could be observed during the entire hospitalization period for most of the examined molecules, including sCTLA-4 (Kong et al. 2020).

\section{TIGIT}

T cell immunoglobulin and ITIM domain (TIGIT) is an inhibitory molecule expressed on NK cells and $\mathrm{T}$ cells $\left(\mathrm{CD}^{+}, \mathrm{CD}^{+}\right.$and $\left.\mathrm{T}_{\text {regs }}\right)$; its expression increases upon cell activation. TIGIT binds to CD155, CD112 and CD113 (in order of decreasing affinity). CD155 can be found on various hematopoietic (DCs, T cells, B cells, macrophages) and non-hematopoietic cells. Similarly to the CTLA-4/CD28 pathway, TIGIT competes for its main ligand (CD155) with other receptors (DNAM-1 and CD-96), which upon binding to $\mathrm{CD} 155$, in contrast, induce activation responses (Harjunpää et al. 2020).

Studies which examined TIGIT expression in COVID-19 patients offer conflicting results. No difference in TIGIT expression between healthy controls, mild and severe COVID-19 patients was described by Herrmann et al. (2020), instead even a decreased trend of its expression (significantly in subset of effector memory CD4 ${ }^{+}$cells) in COVID-19 patients compared to healthy controls was observed (Herrmann et al. 2020). Similar results were reported by Schultheiß et al. (2020): the level of expression of TIGIT on $\mathrm{CD}^{+}$cells and $\mathrm{CD}^{+}$cells was similar to that of healthy controls, however, it was significantly decreased on NK cells in COVID-19 patients with active disease (Schultheiß et al. 2020).

Conflicting results were published by Spanish authors. In a study which followed COVID-19 patients with different disease severity (asymptomatic, non-ICU and ICU) and compared the results to healthy controls, TIGIT expression on $\mathrm{CD}^{+}$cells was significantly lower in non-ICU patients than in both healthy controls and ICU patients, and on $\mathrm{CD}^{+}$cells in non-ICU and asymptomatic patients than in the control group. Control tests were performed on a subgroup of hospitalized patients and confirmed lower levels of $\mathrm{TIGIT}^{+} \mathrm{CD} 4^{+}$, $\mathrm{PD}^{+} \mathrm{CD}^{+}$and $\mathrm{PD} 1^{+} \mathrm{CD} 8^{+}$cells in recovered patients than in healthy donors. The expression of activation markers HLA-DR and CD38 correlated positively with $\mathrm{CD}^{+}{ }^{+} \mathrm{TIGIT}^{+}$and $\mathrm{CD} 4{ }^{+} \mathrm{PD}-1^{+}$cells, while $\mathrm{CD} 45 \mathrm{RA}^{+}$and $\mathrm{TIGIT}^{+} \mathrm{CD} 4^{+}$and $\mathrm{TIGIT}^{+} \mathrm{CD}^{+}$cells correlated negatively. No significant difference was found in TIGIT expression between survivors and non-survivors in nonICU groups of patients (Gutiérrez-Bautista et al. 2020).

In contrast to these findings, Zheng et al. (2020) detected increased expression of TIGIT on $\mathrm{CD}^{+}$cells in both mild and severe COVID-19 patients compared to 
healthy controls and on $\mathrm{CD}^{+}$cells in healthy and mild cases compared to severe COVID-19 patients. In a correlation network analysis, increased expression of TIGIT on $\mathrm{CD}^{+}$cells was significantly related to disease progression (Zheng et al. 2020). TIGIT was also over-expressed on $\mathrm{CD}^{+}$cells in both hospitalized and non-hospitalized COVID-19 patients compared to healthy controls, and its expression remained increased on $\mathrm{CD}^{+}$cells during the convalescent phase in a non-hospitalized subpopulation. Simultaneously, the proportion of $\mathrm{CD}^{+}$cells expressing TIGIT increased over time in non-hospitalized patients. TIGIT frequencies on $\mathrm{CD}^{+}$and $\mathrm{CD} 8^{+}$cells in a non-hospitalized group, correlated with age (Files et al. 2021).

In a longitudinal study which investigated the COVID-19 recovery period, numerous parameters were examined in patients with a history of COVID-19 infection at two time points: 1.3 and then 6.1 months after infection. Even if the disease course in the studied population was skewed towards milder forms, various perturbations in the immune profile persisted. Among other changes, the MFI of $\mathrm{TIGIT}^{+} \mathrm{CD}^{+}$and $\mathrm{TIGIT}^{+} \mathrm{CD}^{+}$ cells was lower at both time points in COVID-19 patients than in healthy controls (hence significant differences obtained only for time point 6.1 months after the infection). Regarding longitudinal variations, the MFI of $\mathrm{TIGIT}^{+} \mathrm{CD} 4^{+}$and $\mathrm{TIGIT}^{+} \mathrm{CD} 8$ was significantly lower 6.1 months after infection than 1.3 months after infection. Significantly lower MFI of TIGIT expression on central memory $\quad \mathrm{CD}^{+} \quad$ cells $\left(\mathrm{CD} 8^{+} \mathrm{T}_{\mathrm{CM}}\right)$, cycling $\mathrm{CD}^{+}\left(\mathrm{Ki} 7^{+} \mathrm{CD}^{+}\right)$and $\mathrm{CD}^{+}\left(\mathrm{Ki}^{+} 7^{+} \mathrm{CD} 8^{+}\right)$cells was seen at both time points in patients with history of COVID-19 than in healthy controls. However, the described abnormalities did not correlate with persistence of symptoms nor overall health status (Breton et al. 2021).

\section{BTLA}

$\mathrm{B}$ and T lymphocyte attenuator (BTLA; CD 272) is a member of co-inhibitory receptors. Its expression on $\mathrm{CD}^{+}$and $\mathrm{CD}^{+}$cells is constitutive and down-regulated during $\mathrm{T}$ cell activation and differentiation, and hence, typically, naive cells express it more than memory cells (Otsuki et al. 2006).

The expression of BTLA was significantly higher on both $\mathrm{CD}^{+}$and $\mathrm{CD}^{+}$cells in COVID-19 patients with active disease than in healthy controls, but it remained unchanged on NK cells (Schultheiß et al. 2020).

Focusing on the subsets of $\mathrm{CD}^{+}$cells,
Herrmann et al. (2020) reported that the decrease in BTLA expression in transient and effector memory $\mathrm{CD}^{+}$cells was significantly less pronounced in COVID-19 patients than in healthy controls.

\section{CD224}

Cluster of differentiation 244 (CD244) is an immunoregulatory receptor expressed on selected cells from both lymphoid and myeloid lineages ( $\mathrm{T}$ cells, NK cells, basophils, monocytes, DCs, MDSC) and binds CD48. Based on the interactions of its intracellular domain with different cytoplasmic adaptor molecules, depending on their concentration, availability and the level of expression of the receptor itself, it may transfer either inhibitory or activating signals (inhibitory signals in the case of high CD244 expression, activating signals in the case of low CD244 expression). Similarly to other immune checkpoint inhibitors, variances in CD244 expression were associated with pathologic conditions, i.e. chronic infections and cancer (Agresta et al. 2018).

The level of expression of CD244 on $\mathrm{CD}^{+}$and $\mathrm{CD} 8^{+}$cells was significantly higher in both severe and mild COVID-19 patients than in healthy donors; however, no significant difference between the two severity groups of COVID-19 patients was observed (Li et al. 2020).

\section{VISTA}

V-domain Ig suppressor of $\mathrm{T}$ cell activation ( $V$-set immunoregulatory receptor, VSIR, VISTA) is a transmembrane protein acting as an immune checkpoint with suppressive effects on $\mathrm{CD} 4^{+}$and $\mathrm{CD}^{+}$cells (Lines et al. 2014). VISTA was up-regulated on $\mathrm{CD} 4^{+}$and $\mathrm{CD} 8^{+}$ in mild and severe COVID-19 patients compared to healthy patients (Rendeiro et al. 2020).

\section{IDO-1}

Indoleamine 2,3 dioxygenase (IDO) is an intracellular enzyme recognized for its participation in metabolic immune regulation by catabolising tryptophan. Expressed in various cells, including APC, its effects are not limited to cells producing IDO, but through secreted metabolites and restricted access to tryptophan, it spreads to neighboring cells, leading to suppression of immune responses with important consequences under physiological and pathological circumstances (Munn et al. 2013). 
Tomić et al. (2021) detected higher percentages of $\mathrm{ILT}^{+}{ }^{+}, \mathrm{PD}_{-\mathrm{L}}{ }^{+}$and IDO- ${ }^{+}$Mo-MDSC (Monocytic Myeloid-Derived Suppressor Cells) in severe COVID-19 patients than in mild cases and healthy donors. However, in severe patients, the expression of PD-L1, ILT-3 and IDO-1 was decreased in monocytes and low in neutrophils and polymorphonuclear myeloid-derived suppressor cells (PMN-MDSC) and eMDSC (Tomić et al. 2021).

\section{Therapeutic perspectives}

Regarding the increasing number of reports on the role of immune checkpoints in the pathophysiology of cancer, they have become an important therapeutic target in the management of several malignant diseases since 2011 (Gambichler et al. 2020). The COVID-19 pandemic has raised several concerns regarding the safety of their use and their possible usefulness in the treatment of COVID-19 patients (Fig. 3) (Bersanelli et al. 2020, Vivarelli et al. 2021, Gambichler et al. 2020, Chiappelli et al. 2020).

The risk of ICI pneumotoxicity and viral pneumonia overlap, possible difficulties of their differential diagnosis and eventual triggering or enhancement of cytokine release syndrome due to inhibition of immune checkpoint molecules should be taken into account on one hand. On the other hand, the possibility of reversing exhausted phenotype of lymphocytes supports the idea of ICI use in these patients (Pezeshki et al. 2021, Shen et al. 2020). Clinical studies are needed to resolve these questions. In the following text, we summarize available evidence.

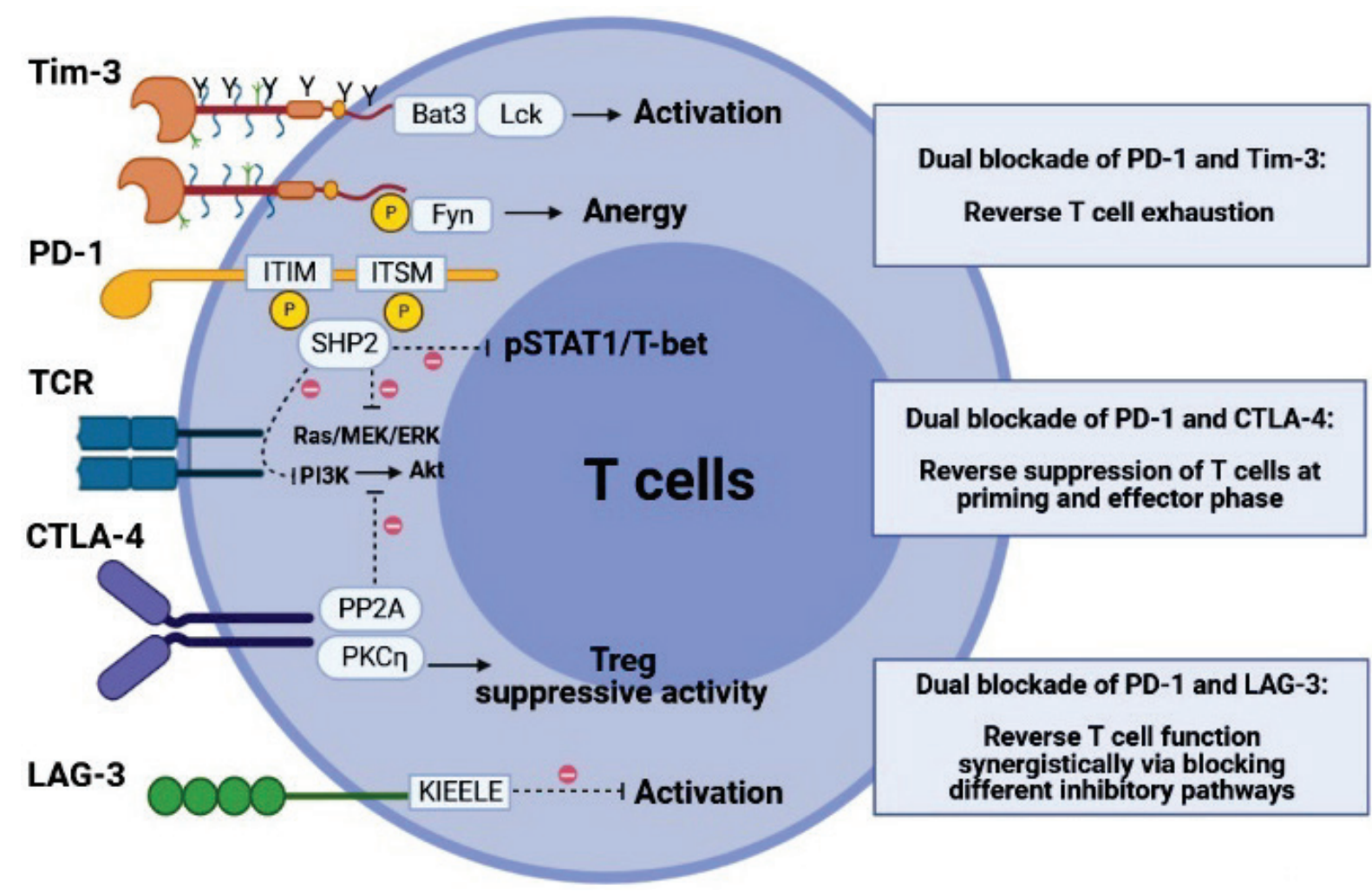

Fig. 3. Potential therapeutic intervention of immune inhibitory receptors in association with cancer and chronic infection. Blockade of the signaling pathway of representative IRs can improve the function and activation of T cells. Bat3, which promotes activation of TCR and acceptance of Fyn, which induces T cell energy. The interaction between phosphatases induced by PD-1 and kinases recruited by Tim-3 might induce T cell exhaustion. PD-1 inhibits PI3K/Akt, Ras/MEK/ERK and p-STAT1/T-bet pathways via SHP-2 to its phosphorylated ITSM motif. CTLA-4 inhibits PI3K/Akt downstream of TCR activation via PP2A in conventional T cells and suppresses activity to $T_{\text {reg }}$ via PKC-h. Inhibition of T cell activity by LAG-3, which contains the KIEELE motif, occurs in an unknown signalling path (adapted from Li et al. 2017). (Created in BioRender.com).

Up to now, monoclonal antibodies against CTLA-4 (ipilimumab), PD-1 (pembrolizumab, nivolumab, cemiplimab) and its ligand PD-L1 (durvalumab, atezolizumab, avelumab) have already been in use with cancer patients (Gambichler et al. 2020). Since immunotherapy with immune checkpoint inhibitors 
(ICI) is associated with restoration of cellular immunocompetence, these patients are likely to be more immunocompetent than those treated with chemotherapy (Bersanelli et al. 2018, Bersanelli et al. 2020). In general, the therapy with ICI was not associated with an increased risk of acquired infections (Gambichler et al. 2020).

Pneumotoxicity is a well-known immune-related adverse event of ICI to which patients with underlying lung diseases were shown to be prone. One of suggested risks concerning treatment with ICI in the era of COVID-19 is possible overlap between coronavirus interstitial pneumonia and ICI-related pneumonitis (Bersanelli et al. 2020). There is also a need to carefully differentiate between these two entities, as they might have similar clinical and radiographic presentation (Chang et al. 2020). However, no link between seasonality (winter months with higher frequencies of respiratory infections) and development of irAE was observed (Shah et al. 2020). Another aspect which should not be overseen is the possible contribution of ICI to the development of cytokine release syndrome (CRS) and deterioration of the course of COVID-19 (Rotz et al. 2017, Bersanelli et al. 2020).

Viral clearance might be facilitated, however, by a blockade of checkpoint inhibitors. This could be beneficial (Sullivan et al. 2020) as several studies have reported that increased expression of inhibitory molecules is related to unfavorable disease outcome in COVID-19 patients (Diao et al. 2019, Zheng et al. 2020, Bobcakova et al. 2021, Zheng et al. 2020). Restoration of normal $\mathrm{T}$ cell function might prevent the disease progression (Vivarelli et al. 2021).

Recently, treatment with pembrolizumab lead to decreased viral loads together with increased $\mathrm{CD}^{+}$and $\mathrm{CD}^{+}$activity in five out of eight patients with progressive multifocal leukoencephalopathy (Cortese et al. 2019). In sepsis, administration of immune checkpoint inhibitors did not provoke hypercytokinemia or cytokine storm and suggested restoration of immune status in a Phase Ib study (Hotchkiss et al. 2019, Hotchkiss et al. 2019). PD-1/PD-L1 pathway was shown to be relevant during persistent viral infection. In HIV patients, its blockade lead to an increase of HIV-specific $\mathrm{CD}^{+}$cells and restored $\mathrm{CD}^{+}$functions (Day et al. 2006).

Up to now, increasing evidence about the impact of ICI on disease course in cancer patients is becoming available. Although a case of rapid progression with fatal outcome in a patient with a previously long-term stable metastatic lung cancer treated by nivolumab was described (Bonomi et al. 2020), an uncomplicated COVID-19 course was reported in amelanoma patient with lung metastases undergoing treatment with pembrolizumab (Pala et al. 2021). In a study by Luo et al. (2020), anti-PD1 treatment did not affect the severity of COVID-19 in patients with lung cancer (Luo et al. 2020). Similarly, the first results of the TERAVOLT study do not suggest a difference in survival rate based on the type of therapy (including immunotherapy) in patients with lung cancer (Garassino et al. 2020). Likewise, a study based on the Spanish registry of melanoma patients treated with anti-PD1 did not show increased risk of death when infected with SARS-CoV-2 (Gonzalez-Cao et al. 2020). In another retrospective study in cancer patients, it was concluded that ICI did not increase the risk of becoming infected with or death from COVID-19 (Klebanov et al. 2021). In the German melanoma registry, 13 patients on ICI with COVID-19 were identified; however, most patients had an asymptomatic or a mild-to-moderate disease course, two patients required hospitalization (one in ICU), but none of them died (Moritz et al. 2021). A multicenter study, including centers from North America, Europe and Australia, has shown that overall, mortality due to COVID-19 in ICI-treated cancer patients was comparable to mortality due to COVID-19 previously reported in cancer patients. In-hospital mortality was higher than previously reported for cancer patients and related to COVID-19 in 50\% of cases. A combination of ICI was evaluated as an independent risk factor for hospital admission (Rogiers et al. 2021). Surprisingly, preliminary data from Italy based on a comparison of seroconversion rates against SARS-CoV-2 in patients with malignant diseases treated with chemotherapy and ICI suggested that ICI might be protective factor against SARS-CoV-2 infection (Isgrò et al. 2021).

Unlike major surgery or chemotherapy, age and treatment with ICI were identified as risk factors for hospitalization and severe course of COVID-19 in a population of 432 cancer patients with COVID-19, (Robilotti et al. 2020). Dipasquale et al. (2021) hypothesized that anti PD-L1 agent acts as a primer for the development of ICI-related pneumonia in patients with squamous head and neck cancer with recent asymptomatic COVID-19 infection. However, lung toxicity was graded as grade 1, and regarding positive impact on malignant disease, immunotherapy was restarted after 6 weeks with no progression of 
pneumopathy (Dipasquale et al. 2021).

It is not surprising that several studies intend to analyze the effect of ICI in COVID-19 patients with (NCT04333914) or without (NCT04413838; NCT04268537; NCT04343144; NCT04356508) underlying malignant disease (Vivarelli et al. 2013). To avoid the risk of cytokine release syndrome, a combination of ICI with anti-IL6R or anti-IL1R was suggested (Bonam et al. 2020, Toor et al. 2021, Vivarelli et al. 2021). Other possible experimental approaches were suggested for inclusion in the management of COVID-19. VISTA is an immunoregulatory receptor constitutively expressed on myeloid and T cells and is downregulated upon activation. VISTA agonists could suppress the cytokine storm mediated mostly by cytokines released from monocytes and macrophages (Eltanbouly et al. 2021). Timing of these therapeutic interventions is presumed a key factor in treatment outcome and their effectiveness (Toor et al. 2021).

\section{Conclusions}

Currently, the terms "immunity" in association with "COVID-19" are one of the most searched terms in bibliographic databases. This is understandable, because immune system is one of the main regulatory systems of the human body and plays a key role in ongoing SARS-CoV-2 infection. Interaction between the virus and an individual's immune system leads to specific clinical manifestation (Paces et al. 2020).

A number of clinical studies are trying to elucidate the involvement of the immune system in progression of COVID-19 and reveal early prognostic biomarkers. It was confirmed by several authors, that selected inhibitory immune checkpoint molecules are significantly up-regulated in patients with severe course of the disease. Down-regulation of these markers could hence serve as a positive prognostic marker and possible therapeutic target. However, results vary between different authors and probably depend on exact timing of examination (Bobcakova et al. 2021).

An interesting therapeutic approach for patients with COVID-19 would be to target pathways of immunosuppressive modifying molecules to re-activate the exhausted phenotype of $\mathrm{T}$ cells, although clinical trials, which investigate the use of ICI in COVID-19 patients, are still ongoing (Vivarelli et al. 2021).

To conclude, further studies are needed to exactly specify the function of inhibitory immune checkpoint molecules in the immune response against SARS-CoV-2 and possible use of ICI in COVID-19 patients.

\section{Conflict of Interest}

There is no conflict of interest.

\section{Acknowledgements}

This publication has been produced with the support of the project KEGA 048UK-4/2021 and Integrated Infrastructure Operational Program for the project: Creation of a Digital Biobank to support the systemic public research infrastructure, ITMS: 313011AFG4, co-financed by the European Regional Development Fund.

\section{References}

ABEL A, STEEG C, AMINKIAH F, ADDAI-MENSAH O, ADDO M, GAGLIANI N, CASAR C, YAR DD, OWUSU-DABO E, JACOBS T, MACKROTH MS: Differential expression pattern of co-inhibitory molecules on CD4+ $\mathrm{T}$ cells in uncomplicated versus complicated malaria. Sci Rep 8: 4789, 2018. https://doi.org/10.1038/s41598-018-22659-1

ACKERMANN C, SMITS M, WOOST R, EBERHARD JM, PEINE S, KUMMER S, MARGET M, KUNTZEN T, KWOK W, LOHSE AW, JACOBS T, BOETTLER T, SCHULZE ZUR WIESCH J: HCV-specific CD4+ T cells of patients with acute and chronic HCV infection display high expression of TIGIT and other co-inhibitory molecules. Sci Rep 9: 10624, 2019. https://doi.org/10.1038/s41598-019-47024-8

AGRESTA L, HOEBE KHN, JANSSEN EM: The emerging role of CD244 signaling in immune cells of the tumor microenvironment. Front Immunol 9: 2809, 2018. https://doi.org/10.3389/fimmu.2018.02809

ALSAAB HO, SAU S, ALZHRANI R, TATIPARTI K, BHISE K, KASHAW SK, IYER AK: PD-1 and PD-L1 checkpoint signaling inhibition for cancer immunotherapy: Mechanism, combinations, and clinical outcome. Front Pharmacol 8: 561, 2017. https://doi.org/10.3389/fphar.2017.00561 
BARBER DL, WHERRY EJ, MASOPUST D, ZHU B, ALLISON JP, SHARPE AH, FREEMAN GJ, AHMED R: Restoring function in exhausted CD8 T cells during chronic viral infection. Nature 439: 682-687, 2006. https://doi.org/10.1038/nature04444

BERSANELLI M, GIANNARELLI D, CASTRIGNANÒ P, FORNARINI G, PANNI S, MAZZONI F, TISEO M, ROSSETTI S, GAMBALE E, ROSSI E, PAPA A, CORTELLINI A, LOLLI C, RATTA R, MICHIARA M, MILELLA M, DE LUCA E, SORARÙ M, MUCCIARINI C, ATZORI F, BANNA GL, LA TORRE L, ET AL.: Influenza vaccine indication during therapy with immune checkpoint inhibitors: A transversal challenge. The INVIDIA study. Immunotherapy 10: 1229-1239, 2018. https://doi.org/10.2217/imt-2018-0080

BERSANELLI M: COVID-19 and the newly rediscovered multidisciplinarity. Immunotherapy 12: 1101-1103, 2020. https://doi.org/10.2217/imt-2020-0205

BLACKBURN SD, SHIN H, HAINING WN, ZOU T, WORKMAN CJ, POLLEY A, BETTS MR, FREEMAN GJ, VIGNALI DA, WHERRY EJ: Coregulation of CD8+ T cell exhaustion by multiple inhibitory receptors during chronic viral infection. Nat Immunol 10: 29-37, 2009. https://doi.org/10.1038/ni.1679

BLANK CU, HAINING WN, HELD W, HOGAN PG, KALLIES A, LUGLI E, LYNN RC, PHILIP M, RAO A, RESTIFO NP, ET AL.: Defining 'T cell exhaustion'. Nat Rev Immunol 19: 665-674, 2019. https://doi.org/10.1038/s41577-019-0221-9

BOBCAKOVA A, PETRISKOVA J, VYSEHRADSKY R, KOCAN I, KAPUSTOVA L, BARNOVA M, DIAMANT Z, JESENAK M: Immune profile in patients with COVID-19: Lymphocytes exhaustion markers in relationship to clinical outcome. Front Cell Infect Microbiol 11: 646688, 2021. https://doi.org/10.3389/fcimb.2021.646688

BONAM SR, KAVERI SV, SAKUNTABHAI A, GILARDIN L, BAYRY J: Adjunct immunotherapies for the management of severely ill COVID-19 patients. Cell Rep Med 1: 100016, 2020. https://doi.org/10.1016/j.xcrm.2020.100016

BONIFACIUS A, TISCHER-ZIMMERMANN S, DRAGON AC, GUSSAROW D, VOGEL A, KRETTEK U, GÖDECKE N, YILMAZ M, KRAFT ARM, HOEPER MM, ET AL.: COVID-19 immune signatures reveal stable antiviral $\mathrm{T}$ cell function despite declining humoral responses. Immunity 54: 340-354.e6, 2021. https://doi.org/10.1016/j.immuni.2021.01.008

BONOMI L, GHILARDI L, ARNOLDI E, TONDINI CA, BETTINI AC: A rapid fatal evolution of Coronavirus Disease-19 in a patient with advanced lung cancer with a long-time response to nivolumab. J Thorac Oncol 15: e83-e85, 2020. https://doi.org/10.1016/j.jtho.2020.03.021

BRETON G, MENDOZA P, HÄGGLÖF T, OLIVEIRA TY, SCHAEFER-BABAJEW D, GAEBLER C, TURROJA M, HURLEY A, CASKEY M, NUSSENZWEIG MC: Persistent cellular immunity to SARS-CoV-2 infection. J Exp Med 218: e20202515, 2021. https://doi.org/10.1084/jem.20202515

BUTLER NS, MOEBIUS J, PEWE LL, TRAORE B, DOUMBO OK, TYGRETT LT, WALDSCHMIDT TJ, CROMPTON PD, HARTY JT: Therapeutic blockade of PD-L1 and LAG-3 rapidly clears established bloodstage Plasmodium infection. Nat Immunol 13: 188-4195, 2011. https://doi.org/10.1038/ni.2180

CHAN JF, KOK KH, ZHU Z, CHU H, TO KK, YUAN S, YUEN KY: Genomic characterization of the 2019 novel human-pathogenic coronavirus isolated from a patient with atypical pneumonia after visiting Wuhan. Emerg Microbes Infect 9: 221-236, 2020. https://doi.org/10.1080/22221751.2020.1719902

CHANG HL, WEI PJ, WU KL, HUANG HL, YANG CJ: Checkpoint inhibitor pneumonitis mimicking COVID-19 infection during the COVID-19 pandemic. Lung Cancer 146: 376-377, 2020. https://doi.org/10.1016/j.lungcan.2020.06.013

CHEMNITZ JM, PARRY RV, NICHOLS KE, JUNE CH, RILEY JL: SHP-1 and SHP-2 associate with immunoreceptor tyrosine-based switch motif of programmed death 1 upon primary human $\mathrm{T}$ cell stimulation, but only receptor ligation prevents T cell activation. J Immunol 173: 945-954, 2004. https://doi.org/10.4049/jimmunol.173.2.945

CHEN N, ZHOU M, DONG X, QU J, GONG F, HAN Y, QIU Y, WANG J, LIU Y, WEI Y, XIA J, YU T, ZHANG X, ZHANG L: Epidemiological and clinical characteristics of 99 cases of 2019 novel coronavirus pneumonia in Wuhan, China: A descriptive study. Lancet 395: 507-513, 2020. https://doi.org/10.1016/S0140-6736(20)30211-7

CHIAPPELLI F, KHAKSHOOY A, GREENBERG G: CoViD-19 immunopathology and immunotherapy. Bioinformation 16: 219-222, 2020. https://doi.org/10.6026/97320630016219 
CORTESE I, MURANSKI P, ENOSE-AKAHATA Y, HA SK, SMITH B, MONACO M, RYSCHKEWITSCH C, MAJOR EO, OHAYON J, SCHINDLER MK, BECK E, REOMA LB, JACOBSON S, REICH DS, NATH A: Pembrolizumab treatment for progressive multifocal leukoencephalopathy. N Engl J Med 380: 1597-1605, 2019. https://doi.org/10.1056/NEJMoa1815039

DAY CL, KAUFMANN DE, KIEPIELA P, BROWN JA, MOODLEY ES, REDDY S, MACKEY EW, MILLER JD, LESLIE AJ, DEPIERRES C, MNCUBE Z, DURAISWAMY J, ZHU B, EICHBAUM Q, ALTFELD M, WHERRY EJ, COOVADIA HM, GOULDER PJ, KLENERMAN P, AHMED R, FREEMAN GJ, WALKER BD: PD-1 expression on HIV-specific T cells is associated with T-cell exhaustion and disease progression. Nature 443: 350-354, 2006. https://doi.org/10.1038/nature05115

DEMARIA O, CARVELLI J, BATISTA L, THIBULT ML, MOREL A, ANDRÉ P, MOREL Y, VÉLY F, VIVIER E: Identification of druggable inhibitory immune checkpoints on natural killer cells in COVID-19. Cell Mol Immunol 17: 995-997, 2020. https://doi.org/10.1038/s41423-020-0493-9

Di COSIMO S, MALFETTONE A, PÉREZ-GARCÍA J M, LLOMBART-CUSSAC A, MICELI R, CURIGLIANO G, CORTÉS J: Immune checkpoint inhibitors: A physiology-driven approach to the treatment of coronavirus disease 2019. Eur J Cancer 135: 62-65, 2020. https://doi.org/10.1016/j.ejca.2020.05.026

DIAO B, WANG C, TAN Y, CHEN X, LIU Y, NING L, CHEN L, LI M, LIU Y, WANG G, YUAN Z, FENG Z, ZHANG Y, WU Y, CHEN Y: Reduction and functional exhaustion of $\mathrm{T}$ cells in patients with Coronavirus Disease 2019 (COVID-19). Front Immunol 11: 827, 2020. https://doi.org/10.3389/fimmu.2020.00827

DIPASQUALE A, PERSICO P, LORENZI E, RAHAL D, SANTORO A, SIMONELLI M: COVID-19 lung injury as a primer for immune checkpoint inhibitors (ICIs)-related pneumonia in a patient affected by squamous head and neck carcinoma treated with PD-L1 blockade: a case report. J Immunother Cancer 9: e001870, 2021. https://doi.org/10.1136/jitc-2020-001870

DOOKIE RS, VILLEGAS-MENDEZ A, KROEZE H, BARRETT JR, DRAPER SJ, FRANKE-FAYARD BM, JANSE CJ, MACDONALD AS, COUPER KN: Combinatorial Tim-3 and PD-1 activity sustains antigen-specific Th1 cell numbers during blood-stage malaria. Parasite Immunol 42: e12723, 2020. https://doi.org/10.1111/pim.12723dookie

ELTANBOULY MA, ZHAO Y, SCHAAFSMA E, BURNS CM, MABAERA R, CHENG C, NOELLE RJ: VISTA: A target to manage the innate cytokine storm. Front Immunol 11: 595950, 2021. https://doi.org/10.3389/fimmu.2020.595950

FIFE BT, PAUKEN KE: The role of the PD-1 pathway in autoimmunity and peripheral tolerance. Ann N Y Acad Sci 1217: 45-59, 2011. https://doi.org/10.1111/j.1749-6632.2010.05919.x

FILES JK, BOPPANA S, PEREZ MD, SARKAR S, LOWMAN KE, QIN K, STERRETT S, CARLIN E, BANSAL A, SABBAJ S, LONG DM, KUTSCH O, KOBIE J, GOEPFERT PA, ERDMANN N: Sustained cellular immune dysregulation in individuals recovering from SARS-CoV-2 infection. J Clin Invest 131: e140491, 2021. https://doi.org/10.1172/JCI140491

GAMBICHLER T, REUTHER J, SCHEEL CH, BECKER JC: On the use of immune checkpoint inhibitors in patients with viral infections including COVID-19. J Immunother Cancer 8: e001145, 2020. https://doi.org/10.1136/jitc-2020-001145

GARASSINO MC, WHISENANT JG, HUANG LC, TRAMA A, TORRI V, AGUSTONI F, BAENA J, BANNA G, BERARDI R, BETTINI AC, BRIA E, BRIGHENTI M, CADRANEL J, DE TOMA A, CHINI C, CORTELLINI A, FELIP E, FINOCCHIARO G, GARRIDO P, GENOVA C, ET AL.: COVID-19 in patients with thoracic malignancies (TERAVOLT): First results of an international, registry-based, cohort study. Lancet Oncol 21: 914-922, 2020. https://doi.org/10.1016/S1470-2045(20)30314-4

GIAMARELlOS-BOURBOUliS EJ, NETEA MG, ROVINA N, AKINOSOGLOU K, ANTONIADOU A, ANTONAKOS N, DAMORAKI G, GKAVOGIANNI T, ADAMI ME, KATSAOUNOU P, ET AL.: Complex immune dysregulation in COVID-19 patients with severe respiratory failure. Cell Host Microbe 27: 992-1000.e3, 2020. https://doi.org/10.1016/j.chom.2020.04.009

GONZALEZ-CAO M, ANTONAZAS-BASA M, PUERTOLAS T, MUNOZ-CONSUELO E, MANZANO JL, CARRERA C, MARQUEZ-RODAS I, LOPEZ-CRIADO P, RODRIGUEZ-MORENO JF, GARCIACASTANO A, ET AL.: Cancer immunotherapy does not increase the risk of death by COVID-19 in melanoma patients. MedRxiv 2020. https://doi.org/10.1101/2020.05.19.20106971 
GU D, AO X, YANG Y, CHEN Z, XU X: Soluble immune checkpoints in cancer: production, function and biological significance. J Immunother Cancer 6: 132, 2018. https://doi.org/10.1186/s40425-018-0449-0

GUAN WJ, NI ZY, HU Y, LIANG W-H, OU C-Q, HE J-X, LIU L, SHAN H, LEI C-L, HUI DSC, ET AL.: Clinical characteristics of coronavirus disease 2019 in China. N Engl J Med 382: 1708-1720, 2020. https://doi.org/10.1056/NEJMoa2002032

GUTIÉRREZ-BAUTISTA JF, RODRIGUEZ-NICOLAS A, ROSALES-CASTILLO A, JIMÉNEZ P, GARRIDO F, ANDERSON P, RUIZ-CABELLO F, LÓPEZ-RUZ MÁ: Negative clinical evolution in COVID-19 patients is frequently accompanied with an increased proportion of undifferentiated Th cells and a strong underrepresentation of the Th1 subset. Front Immunol 11: 596553, 2020. https://doi.org/10.3389/fimmu.2020.596553

HARJUNPÄÄ H, GUILLEREY C: TIGIT as an emerging immune checkpoint. Clin Exp Immunol 200: 108-119, 2020. https://doi.org/10.1111/cei.13407

HASAN A, AL-OZAIRI E, AL-BAQSUMI Z, AHMAD R, AL-MULLA F: Cellular and humoral immune responses in Covid-19 and immunotherapeutic approaches. Immunotargets Ther 10: 63-85, 2021. https://doi.org/10.2147/ITT.S280706

HERRMANN M, SCHULTE S, WILDNER NH, WITTNER M, BREHM TT, RAMHARTER M, WOOST R, LOHSE AW, JACOBS T, SCHULZE ZUR WIESCH J: Analysis of co-inhibitory receptor expression in COVID-19 infection compared to acute Plasmodium falciparum malaria: LAG-3 and TIM-3 correlate with T cell activation and course of disease. Front Immunol 11: 1870, 2020. https://doi.org/10.3389/fimmu.2020.01870

HOTCHKISS RS, COLSTON E, YENDE S, ANGUS DC, MOLDAWER LL, CROUSER ED, MARTIN GS, COOPERSMITH CM, BRAKENRIDGE S, MAYR FB, PARK PK, YE J, CATLETT IM, GIRGIS IG, GRASELA DM: Immune Checkpoint Inhibition in Sepsis: A Phase 1b Randomized, Placebo-Controlled, Single Ascending Dose Study of Antiprogrammed Cell Death-Ligand 1 Antibody (BMS-936559). Crit Care Med 47: 632-642, 2019. https://doi.org/10.1097/CCM.0000000000003685

HOTCHKISS RS, COLSTON E, YENDE S, CROUSER ED, MARTIN GS, ALBERTSON T, BARTZ RR, BRAKENRIDGE SC, DELANO MJ, PARK PK, DONNINO MW, TIDSWELL M, MAYR FB, ANGUS DC, COOPERSMITH CM, MOLDAWER LL, CATLETT IM, GIRGIS IG, YE J, GRASELA DM: Immune checkpoint inhibition in sepsis: a Phase $1 \mathrm{~b}$ randomized study to evaluate the safety, tolerability, pharmacokinetics, and pharmacodynamics of nivolumab. Intensive Care Med 45: 1360-1371, 2019. https://doi.org/10.1007/s00134-019$\underline{05704-z}$

HUANG CT, WORKMAN CJ, FLIES D, PAN X, MARSON AL, ZHOU G, HIPKISS EL, RAVI S, KOWALSKI J, LEVITSKY HI, POWELL JD, PARDOLL DM, DRAKE CG, VIGNALI DA: Role of LAG-3 in regulatory T cells. Immunity 21: 503-513, 2004. https://doi.org/10.1016/j.immuni.2004.08.010

HUARD B, PRIGENT P, TOURNIER M, BRUNIQUEL D, TRIEBEL F: CD4/major histocompatibility complex class II interaction analyzed with CD4- and lymphocyte activation gene-3 (LAG-3)-Ig fusion proteins. Eur J Immunol 25: 2718-2721, 1995. https://doi.org/10.1002/eji.1830250949

ISGRÒ MA, VITALE MG, CELENTANO E, NOCERINO F, PORCIELLO G, CURVIETTO M, MALLARDO D, MONTAGNESE C, RUSSO L, ZANALETTI N, AVALLONE A, PENSABENE M, DE LAURENTIIS M, CENTONZE S, PIGNATA S, CANNELLA L, MORABITO A, CAPONIGRO F, BOTTI G, MASUCCI GV, ET AL.: Immunotherapy may protect cancer patients from SARS-CoV-2 infection: a single-center retrospective analysis. J Transl Med 19: 132, 2021. https://doi.org/10.1186/s12967-021-02798-2

JEANNET R, DAIX T, FORMENTO R, FEUILLARD J, FRANÇOIS B: Severe COVID-19 is associated with deep and sustained multifaceted cellular immunosuppression. Intensive Care Med 46: 1769-1771, 2020. https://doi.org/10.1007/s00134-020-06127-x

JESENAK M, BRNDIAROVA M, URBANCIKOVA I, RENNEROVA Z, VOJTKOVA J, BOBCAKOVA A, OSTRO R, BANOVCIN P: Immune parameters and COVID-19 infection - associations with clinical severity and disease prognosis. Front Cell Infect Microbiol 10: 364, 2020. https://doi.org/10.3389/fcimb.2020.00364 
JONES RB, NDHLOVU LC, BARBOUR JD, SHETH PM, JHA AR, LONG BR, WONG JC, SATKUNARAJAH M, SCHWENEKER M, CHAPMAN JM, GYENES G, VALI B, HYRCZA MD, YUE FY, KOVACS C, SASSI A, LOUTFY M, HALPENNY R, PERSAD D, SPOTTS G, HECHT FM, CHUN TW, MCCUNE JM, KAUL R, RINI JM, NIXON DF, OSTROWSKI MA: Tim-3 expression defines a novel population of dysfunctional T cells with highly elevated frequencies in progressive HIV-1 infection. J Exp Med 205: 2763-2779, 2008. https://doi.org/10.1084/jem.20081398

JUBEL JM, BARBATI ZR, BURGER C, WIRTZ DC, SCHILDBERG FA: The role of PD-1 in acute and chronic infection. Front Immunol 11: 487, 2020. https://doi.org/10.3389/fimmu.2020.00487

KISIELOW M, KISIELOW J, CAPOFERRI-SOLLAMI G, KARJALAINEN K: Expression of lymphocyte activation gene 3 (LAG-3) on $\mathrm{B}$ cells is induced by $\mathrm{T}$ cells. Eur $\mathrm{J}$ Immunol 35: 2081-2088, 2005. https://doi.org/10.1002/eji.200526090

KLEBANOV N, PAHALYANTS V, MURPHY WS, THEODOSAKIS N, ZUBIRI L, MONINA KLEVENS R, KWATRA SG, LILLY E, REYNNOLDS KL, SEMENOV YR: Risk of COVID-19 in patients with cancer receiving immune checkpoint inhibitors. Oncologist 26: e898-e901, 2021. https://doi.org/10.1002/onco.13768

KONG Y, WANG Y, WU X, HAN J, LI G, HUA M, HAN K, ZHANG H, LI A, ZENG H: Storm of soluble immune checkpoints associated with disease severity of COVID-19. Signal Transduct Target Ther 5: 192, 2020. https://doi.org/10.1038/s41392-020-00308-2

KURI-CERVANTES L, PAMPENA MB, MENG W, ROSENFELD AM, ITTNER CAG, WEISMAN AR, AGYEKUM RS, MATHEW D, BAXTER AE, VELLA LA, KUTHURU O, APOSTOLIDIS SA, BERSHAW L, DOUGHERTY J, GREENPLATE AR, PATTEKAR A, KIM J, HAN N, GOUMA S, WEIRICK ME, ET AL.: Comprehensive mapping of immune perturbations associated with severe COVID-19. Sci Immunol 5: eabd7114, 2020. https://doi.org/10.1126/sciimmunol.abd7114

LEGAT A, SPEISER DE, PIRCHER H, ZEHN D, FUERTES MARRACO SA: Inhibitory receptor expression depends more dominantly on differentiation and activation than "exhaustion" of human CD8 T cells. Front Immunol 4: 455, 2013. https://doi.org/10.3389/fimmu.2013.00455

LI J, NI L, DONG C: Immune checkpoint receptors in cancer: redundant by design? Curr Opin Immunol 45: 37-42, 2017. https://doi.org/10.1016/j.coi.2017.01.001

LI M, GUO W, DONG Y, WANG X, DAI D, LIU X, WU Y, LI M, ZHANG W, ZHOU H, ZHANG Z, LIN L, KANG Z, YU T, TIAN C, QIN R, GUI Y, JIANG F, FAN H, HEISSMEYER V, SARAPULTSEV A, WANG L, LUO S, HU D: Elevated exhaustion levels of NK and CD8+ T cells as indicators for progression and prognosis of COVID-19 disease. Front Immunol 11: 580237, 2020. https://doi.org/10.3389/fimmu.2020.580237

LIAO M, LIU Y, YUAN J, WEN Y, XU G, ZHAO J, CHENG L, LI J, WANG X, WANG F, LIU L, AMIT I, ZHANG S, ZHANG Z: Single-cell landscape of bronchoalveolar immune cells in patients with COVID-19. Nat Med 8: 842-844, 2020. https://doi.org/10.1038/s41591-020-0901-9

LINES JL, PANTAZI E, MAK J, SEMPERE LF, O'CONNEL S, CEERAZ S, SURIAWINATA AA, YAN S, ERNSTOFF MS, NOELLE R: VISTA is an immune checkpoint molecule for human T cells. Cancer Res 74: 1924-1932, 2014. https://doi.org/10.1158/0008-5472.CAN-13-1504

LUCAS CL, WORKMAN CJ, BEYAZ S, LOCASCIO S, ZHAO G, VIGNALI DAA, SYKES M: LAG-3, TGF- $\beta$, and cell-intrinsic PD-1 inhibitory pathways contribute to CD8 but not CD4 T-cell tolerance induced by allogeneic BMT with anti-CD40L. Blood 117: 5532-5540, 2011. https://doi.org/10.1182/blood-2010-11-318675

LUO J, RIZVI H, EGGER JV, PREESHAGUL IR, WOLCHOK JD, HELLMANN MD: Impact of PD-1 blockade on severity of COVID-19 in patients with lung cancers. Cancer Discov 10: 1121-1128, 2020. https://doi.org/10.1158/2159-8290.CD-20-0596

MARTÍN-QUIRÓS A, MAROUN-EID C, AVENDAÑO-ORTIZ J, LOZANO-RODRÍGUEZ R, QUIROGA JV, TERRÓN V, MONTALBÁN-HERNÁNDEZ K, GARCÍA-GARRIDO MA, DEL VAL EM, DEL BALZO-CASTILLO A: Potential role of the galectin-9/TIM-3 axis in the disparate progression of SARS-CoV-2 in a married couple: A case report. Biomed Hub 6: 48-58, 2021. https://doi.org/10.1159/000514727

MARUHASHI T, SUGIURA D, OKAZAKI I, OKAZAKI T: LAG-3: from molecular functions to clinical applications. J Immunother Cancer 8: e001014, 2020. https://doi.org/10.1136/jitc-2020-001014 
MCLANE LM, ABDEL-HAKEEM MS, WHERRY EJ: CD8 T cell exhaustion during chronic viral infection and cancer. Annu Rev Immunol 37: 457-495, 2019. https://doi.org/10.1146/annurev-immunol-041015-055318

MENACHERY VD, SCHÄFER A, BURNUM-JOHNSON KE, MITCHELL HD, EISFELD A, WALTERS KB, NICORA CD, PURVINE SO, CASEY CP, MONROE ME, WEITZ KK, STRATTON KG, WEBBROBERTSON BJM, GRALINSKI LE, METZ TO, SMITH RD, WATERS KM, SIMS AC, KAWAOKA Y, BARIC RS: MERS-CoV and H5N1 influenza virus antagonize antigen presentation by altering the epigenetic landscape. Proc Natl Acad Sci U S A 115: E1012-E1021, 2018. https://doi.org/10.1073/pnas.1706928115

MORITZ RKC, GUTZMER R, ZIMMER L, MEIER F, AHMED MS, SELL S, SCHLAAK M, KAPP F, SACHSE MM, HAFERKAMP S, WELZEL J, KÄHLER KC, WEICHENTHAL M: SARS-CoV-2 infections in melanoma patients treated with PD-1 inhibitors: A survey of the German ADOREG melanoma registry. Eur J Cancer 144: 382-385, 2021. https://doi.org/10.1016/j.ejca.2020.11.015

MUNN DH, MELLOR AL: Indoleamine 2,3 dioxygenase and metabolic control of immune responses. Trends Immunol 34: 137-143, 2013. https://doi.org/10.1016/j.it.2012.10.00

OTSUKI N, KAMIMURA Y, HASHIGUCHI M, AZUMA M: Expression and function of the B and T lymphocyte attenuator (BTLA/CD272) on human T cells. Biochem Biophys Res Commun 344: 1121-1127, 2006. https://doi.org/10.1016/j.bbrc.2006.03.242

PACES J, STRIZOVA Z, SMRZ D, CERNY J: COVID-19 and the immune system. Physiol Res 69: 379-388, 2020. https://doi.org/10.33549/physiolres.934492

PALA L, CONFORTI F, COCOROCCHIO E, FERRUCCI P, DE PAS MT, STUCCHI S, REPETTO M, SAPONARA M, QUEIROLO P: Course of Sars-CoV2 infection in patients with cancer treated with anti-PD-1: A case presentation and review of the literature. Cancer Invest 39: 9-14, 2021. https://doi.org/10.1080/07357907.2020.1844893

PALMER BE, NEFF CP, LECUREUX J, EHLER A, DSOUZA M, REMLING-MULDER L, KORMAN AJ, FONTENOT AP, AKKINA R: In vivo blockade of the PD-1 receptor suppresses HIV-1 viral loads and improves CD4+ T cell levels in humanized mice. J Immunol 190: 211-219, 2013. https://doi.org/10.4049/jimmunol.1201108

PARRY RV, CHEMNITZ JM, FRAUWIRTH KA, LANFRANCO AR, BRAUNSTEIN I, KOBAYASHI SV, LINSLEY PS, THOMPSON CB, RILEY JL: CTLA-4 and PD-1 receptors inhibit T-cell activation by distinct mechanisms. Mol Cell Biol 25: 9543-9553, 2005. https://doi.org/10.1128/MCB.25.21.9543-9553.2005

PAUKEN KE, WHERRY EJ: Overcoming T cell exhaustion in infection and cancer. Trends Immunol 36: 265-276, 2015. https://doi.org/10.1016/j.it.2015.02.008

PEZESHKI PS, REZAEI N: Immune checkpoint inhibition in COVID-19: risks and benefits. Expert Opin Biol Ther 21: 1173-1179, 2021. https://doi.org/10.1080/14712598.2021.1887131

RENDEIRO AF, CASANO J, VORKAS CK, SINGH H, MORALES A, DESIMONE RA, ELLSWORTH GB, SOAVE R, KAPADIA SN, SAITO K, BROWN CD, HSU JM, KYRIAKIDES C, CHIU S, CAPELLI LV, CACCIAPUOTI MT, TAM W, GALLUZZI L, SIMONSON PD, ELEMENTO O, SALVATORE M, INGHIRAMI G: Profiling of immune dysfunction in COVID-19 patients allows early prediction of disease progression. Life Sci Alliance 4: e202000955, 2020. https://doi.org/10.26508/lsa.202000955

RIZZO P, VIECELI DALLA SEGA F, FORTINI F, MARRACINO L, RAPEZZI C, FERRARI R: COVID-19 in the heart and the lungs: could we "Notch" the inflammatory storm? Basic Res Cardiol 115: 31, 2020. https://doi.org/ 10.1007/s00395-020-0791-5

ROBILOTTI EV, BABADY NE, MEAD PA, ROLLING T, PEREZ-JOHNSTON R, BERNARDES M, BOGLER Y, CALDARARO M, FIGUEROA CJ, GLICKMAN MS, JOANOW A, KALTSAS A, LEE YJ, LUCCA A, MARIANO A, MORJARIA S, NAWAR T, PAPANICOLAOU GA, PREDMORE J, REDELMAN-SIDI G, ET AL.: Determinants of COVID-19 disease severity in patients with cancer. Nat Med 26: 1218-1223, 2020. https://doi.org/10.1016/j.xcrm.2020.100016

ROGIERS A, PIRES DA SILVA I, TENTORI C, TONDINI CA, GRIMES JM, TRAGER MH, NAHM S, ZUBIRI L, MANOS M, BOWLING P, ELKRIEF A, PAPNEJA N, VITALE MG, ROSE AN, BORGERS JSW, ROY S, MANGANA S, PIMENTEL MUNIZ T, COOKSLEY T, ET AL.: Clinical impact of COVID-19 on patients with cancer treated with immune checkpoint inhibition. J Immunother Cancer 9: e001931, 2021. http://dx.doi.org/10.1136/jitc-2020-001931 
ROTZ SJ, LEINO D, SZABO S, MANGINO JL, TURPIN BK, PRESSEY JG: Severe cytokine release syndrome in a patient receiving PD-1-directed therapy. Pediatr Blood Cancer 64: e26642, 2017. https://doi.org/10.1002/pbc.26642

ROWSHANRAVAN B, HALLIDAY N, SANSOM DM: CTLA-4: a moving target in immunotherapy. Blood 131: 58-67, 2018. https://doi.org/10.1182/blood-2017-06-74103

SAHEB SHARIF-ASKARI N, SAHEB SHARIF-ASKARI F, MDKHANA B, AL HEIALY S, ALSAFAR HS, HAMOUDI R, HAMID Q, HALWANI R: Enhanced expression of immune checkpoint receptors during SARS-CoV-2 viral infection. Mol Ther Methods Clin Dev 20: 109-121, 2021. https://doi.org/10.1016/j.omtm.2020.11.002

SHAH KP, SONG H, YE F, MOSLEHI JJ, BALKO JM, SALEM JE, JOHNSON DB: Demographic factors associated with toxicity in patients treated with anti-programmed cell death-1 therapy. Cancer Immunol Res 8: 85955, 2020. https://doi.org/10.1158/2326-6066

SHAHBAZI M, MOULANA Z, SEPIDARKISH M, BAGHERZADEH M, REZANEJAD M, MIRZAKHANI M, JAFARI M, MOHAMMADNIA-AFROUZI M: Pronounce expression of Tim-3 and CD39 but not PD1 defines CD8 $\mathrm{T}$ cells in critical Covid-19 patients. Microb Pathog 153: 104779, 2021. https://doi.org/10.1016/j.micpath.2021.104779

SHEN C, LI Q, WEI Y, LI Y, LI J, TAO J: Management of immune checkpoint therapy for patients with cancer in the face of COVID-19. J Immunnother Cancer 8: e001593, 2020. https://doi.org/10.1136/jitc-2020-001593

SHI Y, WANG Y, SHAO C, HUANG J, GAN J, HUANG X, BUCCI E, PIACENTINI M, IPPOLITO G, MELINO G: COVID-19 infection: the perspectives on immune responses. Cell Death Differ 27: 1451-1454, 2020. https://doi.org/10.1038/s41418-020-0530-3

SCHULTHEIß C, PASCHOLD L, SIMNICA D, MOHME M, WILLSCHER E, VON WENSERSKI L, SCHOLZ R, WIETERS I, DAHLKE C, TOLOSA E, SEDDING DG, CIESEK S, ADDO M, BINDER M: Next-generation sequencing of $\mathrm{T}$ and $\mathrm{B}$ cell receptor repertoires from COVID-19 patients showed signatures associated with severity of disease. Immunity 53: 442-455.e4, 2020. https://doi.org/10.1016/j.immuni.2020.06.024

STARON MM, GRAY SM, MARSHALL HD, PARISH IA, CHEN JH, PERRY CJ, CUI G, LI MO, KAECH SM: The transcription factor FoxO1 sustains expression of the inhibitory receptor PD-1 and survival of antiviral CD8(+) $\mathrm{T}$ cells during chronic infection. Immunity 41: 802-814, 2014. https://doi.org/10.1016/j.immuni.2014.10.013

SULLIVAN RJ, JOHNSON DB, RINI BI, NEILAN TG, LOVLY CM, MOSLEHI JJ, REYNOLDS KL: COVID-19 and immune checkpoint inhibitors: initial considerations. J Immunother Cancer 8: e000933, 2020. https://doi.org/10.1136/jitc-2020-000933

SYN NL, TENG MWL, MOK TSK, SOO RA: De-novo acquired resistance to immune checkpoint tageting. Lancet Oncol 18: e731-e741, 2017. https://doi.org/10.1016/s1470-2045(17)30607-1

TAKAMURA S, TSUJI-KAWAHARA S, YAGITA H, AKIBA H, SAKAMOTO M, CHIKAISHI T, KATO M, MIYAZAWA M: Premature terminal exhaustion of Friend virus-specific effector CD8+ T cells by rapid induction of multiple inhibitory receptors. J Immunol 184: 4696-4707, 2010. https://doi.org/0.4049/jimmunol.0903478

TAN L, WANG Q, ZHANG D, DING J, HUANG Q, TANG YQ, WANG Q, MIAO H: Lymphopenia predicts disease severity of COVID-19: a descriptive and predictive study. Signal Transduct Target Ther 5: 33, 2020. https://doi.org/10.1038/s41392-020-0148-4

TAYLOR PM, ASKONAS BA: Influenza nucleoprotein-specific cytotoxic T-cell clones are protective in vivo. Immunology 58: 417-420, 1986.

TOMIĆ S, ĐOKIĆ J, STEVANOVIĆ D, ILLIĆ N, GRUDEN-MOVSESIJAN A, DINIĆ M, RADOJEVIĆ D, BEKIĆ M, MITROVIĆ N, TOMAŠEVIĆ R, MIKIĆ D, STOJANIVIĆ D, ČOLIĆ M: Reduced expression of autophagy markers and expansion of myeloid-derived suppressor cells correlate with poor $\mathrm{T}$ cell response in severe COVID-19 patients. Front Immunol 12: 614599, 2021. https://doi.org/10.3389/fimmu.2021.614599

TOOR SM, SALEH R, SASIDHARAN NAIR V, TAHA RZ, ELKORD E: T-cell responses and therapies against SARS-CoV-2 infection. Immunology 162: 30-43, 2021. https://doi.org/10.1111/imm.13262

TRIEBEL F, JITSUKAWA S, BAIXERAS E, ROMAN-ROMAN S, GENEVEE C, VIEGAS-PEQUIGNOT E, HERCEND T: LAG-3, a novel lymphocyte activation gene closely related to CD4. J Exp Med 171: 1393-1405, 1990. https://doi.org/10.1084/jem.171.5.1393 
VARCHETTA S, MELE D, OLIVIERO B, MANTOVANI S, LUDOVISI S, CERINO A, BRUNO R, CASTELLI A, MOSCONI M, VECCHIA M, RODA S, SACHS M, KLERSY C, MONDELLI MU: Unique immunological profile in patients with COVID-19. Cell Mol Immunol 18: 604-612, 2021. https://doi.org/10.1038/s41423-020-00557-9

VAŠKU゚ A: Covid-19 infection and the host genetic predisposition: does it exist? Physiol Res 69: 511-514, 2020. https://doi.org/10.33549/physiolres.934504

VIVARELLI S, FALZONE L, TORINO F, SCANDURRA G, RUSSO G, BORDONARO R, PAPPALARDO F, SPANDIDOS DA, RACITI G, LIBRA M: Immune-checkpoint inhibitors from cancer to COVID 19: A promising avenue for the treatment of patients with COVID 19 (Review). Int J Oncol 58: 145-157, 2021. https://doi.org/10.3892/ijo.2020.5159

WORKMAN CJ, DUGGER KJ, VIGNALI DA: Cutting edge: molecular analysis of the negative regulatory function of lymphocyte activation gene-3. J Immunol 169: 5392-5395, 2002. https://doi.org/10.4049/jimmunol.169.10.5392

WORKMAN CJ, VIGNALI DA: The CD4-related molecule, LAG-3 (CD223), regulates the expansion of activated T cells. Eur J Immunol 33: 970-979, 2003. https://doi.org/10.1002/eji.200323382

WORKMAN CJ, WANG Y, EL KASMI KC, PARDOLL DM, MURRAY PJ, DRAKE CG, VIGNALI DA: LAG-3 regulates plasmacytoid dendritic cell homeostasis. J Immunol 182: 1885-1891, 2009. https://doi.org/10.4049/jimmunol.0800185

WU C, CHEN X, CAI Y, XIA J, ZHOU X, XU S, HUANG H, ZHANG L, ZHOU X, DU C, ZHANG Y, SONG J, WANG S, CHAO Y, YANG Z, XU J, ZHOU X, CHEN D, XIONG W, XU L, ZHOU F, JIANG J, BAI C, ZHENG J, SONG Y: Risk factors associated with acute respiratory distress syndrome and death in patients with Coronavirus Disease 2019 pneumonia in Wuhan, China. JAMA Intern Med 180: 934-943, 2020. https://doi.org/10.1001/jamainternmed.2020.0994

ZHANG B, ZHOU X, QIU Y, SONG Y, FENG F, FENG J, SONG Q, JIA Q, WANG J: Clinical characteristics of 82 cases of death from COVID-19. PLoS One 15: e0235458, 2020. https://doi.org/10.1371/journal.pone.0235458

ZHENG HY, ZHANG M, YANG CX, ZHANG N, WANG XC, YANG XP, DONG XD, ZHENG YT: Elevated exhaustion levels and reduced functional diversity of $\mathrm{T}$ cells in peripheral blood may predict severe progression in COVID-19 patients. Cell Mol Immunol 17: 541-543, 2020. https://doi.org/10.1038/s41423-020-0401-3

ZHENG M, GAO Y, WANG G, SONG G, LIU S, SUN D, XU Y, TIAN Z: Functional exhaustion of antiviral lymphocytes in COVID-19 patients. Cell Mol Immunol 17: 533-535, 2020. https://doi.org/10.1038/s41423-020-0402-2 